\title{
The New Field of Liquidity and Financial Frictions
}

\author{
David Adler \\ Financial Author and Documentary Producer \\ New York City
}

Illiquidity and other financial frictions are critical to financial markets and the overall economy. This literature review provides a synopsis of academic research in this rapidly developing specialty field, offering insights into liquidity and asset pricing, systemic risk, macro frictions, and new models of the causes of a liquidity crisis.

Liquidity has no agreed-upon or universal definition in economics. The nearest approximation to an uncontested description is that of O'Hara (1995), who makes an analogy to pornography: Liquidity is hard to define, but "you know it when you see it."

Part of the problem of defining liquidity is that the concept arises in very different economic contexts: in the ease of trading a security (market liquidity), in the ease of obtaining funding to trade a security (funding liquidity), and also in terms of the macroeconomy as seen in the 2007-09 liquidity crisis and its ongoing aftermath. Moreover, liquidity, however defined, is hard to measure; even for the U.S. stock market, there is an ongoing research debate about what the best low-frequency liquidity measurement for equities is. Yet, despite these challenges, understanding liquidity in its various guises is critically important for practitioners and policymakers alike. This literature review attempts to summarize the vast and rapidly evolving literature on liquidity in finance. The organization of this review is essentially chronological, paralleling developments in financial economics, which in turn have been spurred by economic events.

The first section of the review focuses on market liquidity and asset pricing, the oldest strand of the liquidity literature. Liquidity-based asset pricing models give insight into the impact of liquidity on the expected returns of numerous asset classes: equities, corporate bonds, off-the-run Treasury bonds, hedge funds, and other assets. These models are agnostic about sources of illiquidity; instead, their central insight is that illiquidity (however defined) affects expected returns in two ways: as a cost and as a risk. That is, investors need to be compensated not only for the difficulty of trading a security but also for the sensitivity of the security to a liquidity shock. The culmination of this research is the liquidity-adjusted capital asset pricing model (CAPM) of Acharya and Pedersen (2005). Empirical research into liquidity and asset pricing is ongoing, with many issues still unresolved.

The second section of this review, chronicling liquidity and the 2007-09 crisis, is essentially an interlude, introducing topics treated in depth in the final section. This crisis section references papers that explain how markets can suddenly turn illiquid. Much of this literature focuses on the shadow banking system, which is based on securitization and on the vulnerability of securitized debt markets to "liquidity spirals." Interestingly, many of the papers modeling the fragility of this system were written before the financial crisis.

The third and final section focuses on the interrelated issues of funding liquidity, systemic risk, and macro frictions, the newest and most active areas of liquidity research. This literature is often highly conceptual yet critically important for understanding markets, particularly during and after a financial crisis. There are many ongoing research strands. Some are focused on funding liquidity, which can be thought of as the amount of available arbitrage capital, which in turn can become constrained during a systemic crisis. Others are concerned with measuring systemic risk and sources of macroeconomic instability. The larger overall research theme is to 
model the macro impact of credit constraints and other financial frictions. This effort involves incorporating a financial sector into macro models; to the surprise of noneconomists, macroeconomic models typically do not include a financial sector, even an illiquid one, or else they give it no special weight. Though most macro finance models are still incomplete, they offer insight into why a liquidity crisis and troubled banking sector can have such a long-lasting and pernicious impact on the macroeconomy.

Taken together, the liquidity literature has a common theme: Financial frictions, such as illiquidity, are critically important to financial markets and the overall economy. Prices can be pushed away from fundamental values and do not necessarily correct immediately. Understanding liquidity, in all its permutations, can help practitioners move beyond paying lip service to liquidity risk and instead devise portfolios and strategies that more precisely protect against it - or exploit it.

What is less clear is how to classify this new field focused on liquidity. Is it part of behavioral finance or traditional finance? Both have claimed it as their own. Like behavioral finance, the new models are a departure from classic frictionless finance and perfectly efficient markets. However, unlike behavioral models, they don't use psychology or investor irrationality. What they do instead is add realistic frictions to standard, efficient market, frictionless models. Perhaps the study of liquidity and financial frictions is best thought of as its own new field, one that has developed a rich set of new financial theories that can explain much about the ongoing crisis and also solve many puzzles in finance.

In this literature review, I hope to convey not only the ideas of this highly academic field in ways that are useful to practitioners but also the excitement and ongoing speed of its development. Because the research is moving so quickly, the reader will notice the pronounced presence of working papers in this review, as well as lurching gaps in the literature, with some papers being highly conceptual and lacking testable predictions and others having strong empirical results but lacking developed theory. Though the review will discuss the limitations of current liquidity research, including the lack of a central unified structural model as well as the general amorphous quality of the field-stemming perhaps from the ill-defined concept of liquidity itself-readers should still come away impressed. ${ }^{1}$ Whereas post-1979 theoretical developments in finance have been described as mostly "a mopping up operation" (Duffie 1992), developments in liquidity and financial friction research have led to a reappraisal. As John Cochrane (2010) of the University of Chicago claimed in his introduction to the Presidential Address to the American Finance Association, "Far from mopping up, I think we're in a second golden age of financial theory."

\section{Part I: Liquidity and Asset Pricing}

In traditional asset pricing models, liquidity plays no role at all because it is assumed away: Markets are frictionless and participants are price takers. Once these assumptions are relaxed, the world changes, not always in expected ways. The vast literature on liquidity and asset pricing instead argues that liquidity is indeed priced and contains both theoretical models and empirical findings detailing how an asset's liquidity affects expected returns. Surprisingly, even perversely, much of this literature is focused on equities, a relatively liquid asset class. Perhaps that is because data for less liquid asset classes are harder to come by.

Liquidity, despite its lack of a formal definition in a market context, can be thought of as the ease of trading a security. This is a multidimensional concept, involving cost and quantity as well as speed. The market liquidity and asset pricing literature is largely agnostic about the source of an asset's relative liquidity; papers focusing on sources of illiquidity, some mentioned below, are generally classified as part of the market microstructure literature, a field distinct from the new liquidity literature. A further distinction is that the microstructure literature is more focused on intraday trading, order flow dynamics, and quantity, whereas the liquidity and asset pricing literature has a longer time horizon and is focused on expected returns. However, as with everything related to liquidity, the boundaries are slippery.

\footnotetext{
${ }^{1}$ The capital asset pricing model would be an example of a central structural model in traditional finance.
} 
This survey of the liquidity and asset pricing literature starts with papers on equities and then discusses papers on other asset classes. It also includes papers on ways to measure liquidity. It largely follows the framework laid out by Amihud, Mendelson, and Pedersen (2005) in their survey. The reader should be aware that when the literature uses the term "liquidity risk," it more often than not means the term in the opposite sense- the risk of illiquidity, or a stock's vulnerability when the market becomes illiquid. In this review, I point out when an author departs from this convention.

Background Reading: Sources of Illiquidity. The illiquidity of an asset can stem from different sources. Different strands of the theoretical literature on market microstructure have emphasized asymmetric information, high transaction costs, order imbalances, and search costs (including the difficulty of locating a counterparty) as the primary reasons for the lack of liquidity.

A foundational paper by Grossman and Miller (1988) states that liquidity is determined by demand and supply. In any market, a buyer does not automatically exist for every seller, but intermediaries can step in and bear the risk while awaiting a final buyer. Grossman and Miller call these market-making intermediaries "suppliers of immediacy." Sudden surges in demand or supply, changes in information, or limits to the risk-bearing capacity of these market makers all can affect the liquidity of a market. Other key papers include Kyle (1985), which emphasizes information asymmetries as a source of illiquidity; others emphasize search costs or order imbalances. Typically, microstructure papers dealing with sources of illiquidity analyze trading mechanisms at a detailed level and perhaps also offer insight as to how markets should be designed and regulated. Far less commonly do they analyze how liquidity affects expected returns. This latter topic has become the focus of the new liquidity literature.

For a comprehensive overview of the market microstructure literature on sources of liquidity, see books by Hasbrouck (2007), Harris (2003), and O'Hara (1995).

Liquidity and Asset Pricing: Equities. Models of liquidity and asset pricing start from the basic insight that there is a cost to trading relatively illiquid securities and that investors need to be compensated for this cost. Though investors may find this obvious, academic research overlooked this cost for a long time because the assumption of frictionless markets is so useful. The first paper to develop and model liquidity's impact on price fully and formally is Amihud and Mendelson (1986). It was to become one of the foundational papers in liquidity and asset pricing research.

Amihud and Mendelson (1986) argue that investors buying a less-than-fully-liquid security recognize there is a transaction cost and demand to be compensated for it in terms of offsetting higher expected returns (lower prices). Here liquidity is characterized by the cost of immediate execution, which is captured in the spread between the bid and the ask price. Compared with a liquid security, an illiquid security will be discounted by these future transaction costs. The greater the illiquidity (here, the spread), the greater the before-cost expected return. Moreover, investors with long time horizons and in no need of immediate trading can accrue these returns.

Amihud and Mendelson's (1986) paper thus introduces many ideas found in the subsequent liquidity literature. One idea is that there are clientele effects when it comes to liquidity, with long-horizon investors choosing illiquid securities. The other idea is that a security's expected return depends on more than just its risk; it also depends on its liquidity and on the compensation for the transaction costs involved. The liquidity-return relation as anticipated by the model was borne out empirically by the authors' test of U.S. stock market data.

This paper transformed academic liquidity research, igniting hundreds of other research efforts to specify liquidity's role in asset pricing. A rare early paper that predates Amihud and Mendelson (1986) is Ibbotson, Diermeier, and Siegel (1984). They argue that, in addition to risk as captured in the CAPM, an asset's "non-risk" characteristics - taxation, marketability, and information costs - affect expected return and, hence, price. Here "marketability" encompasses the concept of liquidity.

The case of restricted stock, as described by Silber (1991), is the clearest empirical example of liquidity's impact on equity pricing. Restricted stock is issued by public companies, often to corporate insiders as a form of compensation, and it cannot be traded on public markets for a specified holding period (two years when Silber's 
paper was written but now one year). Comparing restricted stock with nonrestricted stock of the same company, Silber finds that the restricted stock of creditworthy companies typically sells at more than a $30 \%$ discount compared with nonrestricted stock, which illustrates the impact of liquidity on stock prices.

The next major leap forward in liquidity research is Chordia, Roll, and Subrahmanyam (2000), who show that liquidity has a commonality with marketwide features that goes beyond the characteristics of an individual security's liquidity. That is, liquidity - here defined by five measures, including spread and depth - is not an isolated phenomenon but is highly correlated, affecting all securities. Other papers focusing on commonality in liquidity appeared almost simultaneously, including Huberman and Halka (2001). Moreover, Chordia et al. are able to describe and quantify various aspects of this commonality. Marketwide liquidity varies according to whether the market is going up or down. Spreads widen dramatically in down markets but decrease very slightly in up markets, unlike trading, which increases in both instances.

The larger insight of this research is to introduce the idea that because liquidity is marketwide, it cannot be fully diversified away. The commonality of liquidity means that traders can become stuck, regardless of the individual characteristics of a security. However, securities are not equally sensitive to these marketwide movements, and investors should require those that are more sensitive to have higher expected returns. Put another way, liquidity in these models is on its way to becoming a "risk factor," although Chordia et al. do not use that precise term.

The first paper to fully grapple with the idea that this marketwide liquidity is important for asset pricing is Pástor and Stambaugh (2003). A related innovation in their work is to introduce the notion of a "liquidity beta," which they define as equities' "sensitivities to innovations [shocks] in aggregate liquidity" (p. 2). In this paper, liquidity has explicitly moved beyond just being a characteristic, similar to a cost. The ideas of liquidity and asset pricing now also embrace the idea of a stock's exposure to marketwide liquidity fluctuations. Investors demand higher expected returns for bearing this risk, so the security is priced accordingly. And Pástor and Stambaugh's empirical research reveals this to be true: Stocks with a high liquidity beta tend to have high average returns.

Pástor and Stambaugh (2003) have suffered withering criticism. Their critics describe their paper as more of a statistical exercise than a formal economic model. The criticism is focused mostly on the authors' measure of liquidity (see Holden 2009), on which the whole exercise —and, hence, their empirical results—is based. Nonetheless, the paper sets the stage for a more formal model that can incorporate these two different aspects of liquidity, both of which are priced: liquidity as a cost and liquidity as a risk.

The modeling of the impact of market liquidity on equity prices has culminated, at least to date, in the liquidity-adjusted CAPM of Acharya and Pedersen (2005). Unlike the standard CAPM, which operates in a frictionless economy, the liquidity-adjusted CAPM is rewritten to take into account liquidity frictions.

For their model, Acharya and Pedersen (2005) start with a standard CAPM but augment it with liquidity as a cost and liquidity as a risk. They further refine the idea of liquidity risk into three separate components, or liquidity betas, which can impact expected returns. The first beta, $\beta L 1$, is the covariance of the illiquidity of the asset with the illiquidity of the market; the intuition is that investors want to be compensated for assets that become illiquid when the market does. The second beta, $\beta L 2$, tracks the covariance between a security's return and market liquidity. This beta is typically negative in terms of its effect on expected return because investors will tolerate a lower return for assets that tend to do well when the market turns illiquid. The third beta, $\beta L 3$, captures the covariance between an asset's illiquidity and market returns. This beta is also typically negative in its effect on expected returns because investors will tolerate reduced returns for assets that retain their liquidity when the market does poorly.

The resulting liquidity-adjusted CAPM states that a security's required excess return is a function of the expected illiquidity cost plus the four betas (the three new liquidity betas plus the traditional market beta) times the risk premium.

As Acharya and Pedersen (2005) describe it, "The model gives an integrated view of the existing empirical evidence related to liquidity and liquidity risk. . . The liquidity-adjusted CAPM explains the data better than the standard CAPM" (p. 405). The authors empirically test the predictions of the model by sorting U.S. equities into 25 portfolios by liquidity level. They find that the least-liquid portfolios outperformed, with the difference 
in annualized expected returns between Portfolios 1 and 25 attributable to liquidity being $4.6 \%$ a year, of which $3.5 \%$ is related to differences in liquidity as cost and $1.1 \%$ to differences in liquidity as risk.

The liquidity CAPM is a highly stylized model: Agents live for only two periods and must trade before they die. But the larger idea is simple and intuitive: Investors should care about liquidity risk (however defined) and be compensated for this risk. Lee (2005) tests the liquidity-adjusted CAPM in global markets and finds that liquidity risk is priced and that, moreover, "liquidity risks may be more important in international financial markets than in the U.S." (p. 27).

Further work on the concept of a liquidity beta has been undertaken by Lou and Sadka (2011), who tease apart the differences between a stock's liquidity level (liquidity as a characteristic) and liquidity risk (price sensitivity to a marketwide liquidity shock). They focus on the U.S. stock market during the crisis of 2007-2008 and find that stocks sorted by their level of liquidity showed no cross-sectional return difference during this period. That is, liquidity as a characteristic was not in itself predictive of a stock doing well or badly during market turmoil. Instead, the authors show that stocks with high sensitivity to the overall liquidity of the market - that is, with high liquidity risk - underperformed during the crisis. The striking insight is that liquidity as risk is not necessarily closely correlated with liquidity as cost. This finding contrasts with Acharya and Pedersen's (2005) conclusion that stocks with high liquidity costs also have high liquidity risk; the two are closely correlated because of the general flight to liquidity during down markets. Instead, the intuition that supports Lou and Sadka's finding is that during a crisis, portfolio managers are likely to sell their liquid securities first, believing such action will have a smaller price impact, while they avoid selling their hard-to-trade, illiquid securities.

Additionally, the pricing of liquidity risk is time varying and not static, argue Watanabe and Watanabe (2008). They use a regime-shifting model and find that in one state, which they call "normal" and which occurs $90 \%$ of the time, liquidity risk is not really priced at all. However, in a "high liquidity beta" state, which occurs only $10 \%$ of the time and is associated with high volatility, liquidity risk is highly priced. The transition from the normal state to the high-beta state "is predicted by a rise in trading volume" (p. 3), which in turn reflects increased uncertainty about investors' preferences and future liquidity.

Closed-End Fund Puzzle. The liquidity and asset pricing literature also offers a solution to the closedend fund puzzle. Closed-end funds are mutual funds that issue and float a fixed number of shares via an initial public offering (IPO). The puzzle is that these shares often trade at a discount (or premium) to the fund's underlying net asset value (NAV). A common explanation for the puzzle is investor sentiment: Behavioral economists argue that these funds are usually held by small investors and the fluctuations in the discount are driven by the sentiments of these investors toward closed-end funds. The liquidity asset pricing approach instead argues that the diverging premium is related to the liquidity of the mutual fund shares in comparison with the liquidity of the underlying assets, with the shares tending to have lower transaction costs.

Cherkes, Sagi, and Stanton (2009) build a model to solve the puzzle using this liquidity focus. They argue that the primary reason closed-end funds exist is to allow small investors to buy illiquid securities with minimized transaction costs. Because of this benefit, at the time of their IPO, funds trade at a premium compared with their NAV. This premium is offset somewhat by management fees. Over time, however, new closed-end funds enter the market, driving down the share price of existing funds. With no offsetting premium, their management fee then causes these funds to be traded at a discount to NAV. Examining Morningstar data from 1986 to 2004, Cherkes et al. find strong empirical support for this model, as opposed to sentiment explanations.

Measures of Liquidity. No single measure of liquidity captures all three dimensions of the ease of trading a security: the cost, quantity (in terms of its impact on price), and speed. Additionally, academic research tends to use measures based on low-frequency data (daily or monthly) as opposed to high-frequency intraday trading, in part because of the lack of complete transaction data. For example, low-frequency data for U.S. stock markets go back to 1926, whereas high-frequency data begin in 1993. That is, the low-frequency measures are proxies for the 
more accurate high-frequency liquidity measures. Identifying the best low-frequency liquidity proxies remains a critical and developing area of liquidity research and makes up an entire subfield of the liquidity literature.

Low-frequency measures of liquidity can in turn be broken down into two categories: spread measures and price impact measures. There are no low-frequency measures of the speed category because low-frequency data do not contain any direct or indirect information about speed.

Low-Frequency Spread Measures. Roll (1984) develops a measure for "effective spread." He argues that traders are unlikely to trade at the actual bid or ask price and, instead, most actual trading is done "within the quotes" (receiving a price higher than the bid and paying less than the ask). To estimate this "effective spread," Roll develops an inferred measure based on the "first order serial covariance of price changes" (p. 1127).

Lesmond, Ogden, and Trzcinka (1999) create a proportional bid-ask spread measure. Their proxy for liquidity is derived from the "incidence of zero return days." Zero return days include zero volume days, an obvious indication of a stock's illiquidity. But beyond this—and more subtly—on zero return days, the lack of movement in stock price is a result of illiquidity in the authors' model; whatever trading information the marginal trader may have is outweighed by transaction costs, which introduces the notion that illiquidity involves not just the bid-ask spread but also the opportunity cost of waiting to trade in a market. One noteworthy result of this approach is that the authors are able to estimate effective spreads without having to know actual bid-ask spreads.

Holden (2009) and Goyenko, Holden, and Trzcinka (2009) jointly create the "effective tick" measure, which is a proxy for the effective spread based on price clustering. Holden focuses on how much prices tend to cluster at round number increments (whole dollars, half-dollars, quarters, dimes, and nickels) as opposed to penny increments; more clustering implies larger transaction costs. He then creates a second measure for illiquidity that combines effective tick with Roll-like effective spread measures. This joint measure, called the "Holden measure," combines correlation with clustering approaches.

Low-Frequency Price Impact Measures. Price impact measures attempt to capture the price changes induced by an order flow. Put another way, how much can you trade without moving the price? Perhaps the best known is Amihud's (2002) measure that he calls "ILLIQ," which captures the "daily price response associated with one dollar of volume" (p. 32). ILLIQ can be expressed as

$$
\text { ILLIQ }=\text { Average }[|R|(P \times \mathrm{VOL})]=\text { Average }[|R| /(\text { Dollar volume })] \text {, }
$$

where $R$ is daily return, $P$ is the closing daily price, and VOL is the number of shares traded during the day. For their model, Pástor and Stambaugh (2003) use a measure of price impact they call "gamma," which is related to return reversal in order flow after a volume shock, with less liquid stocks tending to have greater reversals.

Running a Horse Race: Testing These Measures. Goyenko, Holden, and Trzcinka (2009) test these lowfrequency proxies for liquidity against benchmarks of liquidity constructed from high-frequency data. In their words, they run a "horse race" of the low-frequency proxies in common use. The benchmarks they use-bid-ask spread, effective bid-ask spread, and price impact-are compared with and computed from two different highfrequency datasets. The result of the horse race is that most, but not all, of the standard low-frequency proxies for liquidity actually measure liquidity. Among the low-frequency spread measurement standouts are Holden's two measures, as well as Lesmond, Ogden, and Trzcinka's (1999). The low-frequency price impact measures do not do a good job of capturing the magnitude of high-frequency price impact, but they are reasonably correlated with it. Among these measures, the authors note that Pástor and Stambaugh's gamma is "clearly dominated by other measures" (p. 154), with Amihud's among the standouts.

For practitioners, understanding the low-frequency measures (and their limitations) is important if they are to conduct their own backtesting of periods when high-frequency data are not available and other approaches are called for. Caution is required in applying the low-frequency measures because this is still a developing area of research. 
Fixed Income: Treasuries. Liquidity affects the expected return of even the most seemingly liquid asset class of all: U.S. Treasury bonds. Treasuries, when newly issued, are indeed very actively traded, but are less so as they make their way into investors' portfolios and go "off the run" a month or two later, when a new Treasury of the same maturity is issued. That is, there are liquidity differences within Treasuries, with the older, off-the-run securities being less liquid than their newly issued, on-the-run counterparts.

Amihud and Mendelson (1991) investigate these liquidity effects on Treasury yields. The Treasuries they compare have the same maturity and also, of course, the same risk of default, differing only in their liquidity. In their sample of 489 pairs from 1987, the average bid-ask spread for off-the-run Treasuries was 3 bps, compared with $0.78 \mathrm{bps}$ for on-the-run Treasuries. The off-the-run Treasuries had a compensating higher average yield of 43 bps, which the authors take as "robust confirmation of the liquidity effect in asset pricing" (p. 1411).

Fixed Income: Corporate Bonds. The liquidity asset pricing literature for corporate bonds takes as its starting point the puzzle that the yields on corporate bonds are too large to be explained by default risk alone. Researchers attempt to solve this puzzle by identifying the role liquidity may play, if any, in explaining this spread. In general, this research is aided by the fact that expected return is comparatively easier to see in bonds than in equities: It is the yield to maturity, adjusted for expected defaults, if any. The challenge is that it is harder to measure liquidity for individual bonds than for equities, as well as to control for all other effects that might be driving yields.

Numerous empirical papers, such as those by Chen, Lesmond, and Wei (2007) and Longstaff, Mithal, and Neis (2005), find a relationship between liquidity, defined in various ways, and corporate bond yields. The Longstaff et al. paper distinguishes liquidity from default risk effects on bond spreads through the innovation of using the credit default swap (CDS) market as a way to obtain pricing for default risk. Through the use of this approach - although the authors find that the risk of default does explain the majority of yield spread for corporate bonds, particularly for bonds with low ratings- the remaining "non-default component" of spread is priced too, from 20 to 100 bps. Further tests of this "non-default component" show it is only weakly related to tax effects and instead is driven by liquidity. The authors conclude, "These results indicate that there are important individual corporate bond and marketwide liquidity dimensions in spreads" (p. 2215).

A study, similar in spirit but with the slightly different objective of comparing various proxies for bond liquidity, was undertaken by Houweling, Mentink, and Vorst (2005) to see whether liquidity is priced into European corporate bonds. The authors control for default risk, interest rate risks, and also the characteristics of individual bonds: duration and rating, which might also influence spreads. To identify liquidity, the researchers turn to proxies rather than direct measures, which are often hard to obtain for bonds. The proxies for liquidity are issue amount, coupon, age, missing prices, yield volatility, and yield dispersion. (The authors note that for bonds, unlike equities, age is a good proxy for lack of liquidity, interestingly, because older bonds trade less frequently than newly issued bonds and often make their way into buy-and-hold portfolios.)

Following the standard practice in liquidity pricing research for equities, Houweling et al. then create portfolios, sorted by liquidity, of euro-denominated bonds for the period January 1999 through May 2001. They find that liquidity was priced, at least using seven of the eight proxies, with "significant liquidity premiums ranging from 9 to 24 basis points" (p. 1331), depending on the proxy.

Though these papers find liquidity effects on corporate bond pricing, they lack an economic model and, furthermore, do not fully tease apart overall liquidity into liquidity-as-cost and liquidity-as-risk factors, as has been done with equities. This refinement in corporate bond pricing is accomplished by de Jong and Driessen (2006). They focus on how liquidity as a risk could explain corporate spreads and investigate how sensitive corporate bonds are to liquidity shocks. The authors do not measure the liquidity of the bond market directly but instead use liquidity shocks in equity markets and Treasuries as the source of spillover shocks into corporate bonds. They conclude that liquidity as a risk is priced for corporate bond spreads, with the risk exposure greater for lowerrated bonds. In terms of annualized expected returns, the premium for liquidity risk is $0.6 \%$ for long-maturity investment-grade bonds and 1.5\% for below-investment-grade bonds. 
Bongaerts, de Jong, and Driessen (2011) build a formal economic model for corporate bond pricing in which expected returns are a function of both liquidity as a cost and liquidity as a risk. Their model has quantitative predictions that they test using the U.S. corporate bond market from 2004 to 2008 . They have direct measures of transaction prices, which they use to estimate liquidity as a cost for the portfolios they construct. They find only very weak evidence that liquidity as a risk, as opposed to as a cost, played a role in pricing in their sample. Nonetheless, their preliminary conclusion is that the credit spread puzzle for corporate bonds can be explained by both aspects of liquidity, as a cost and as a risk.

For researchers and practitioners attempting to calculate their own liquidity factors for corporate bonds, Chacko, Das, and Fan (2011) propose one practical solution. Most conventional measures are hard to implement because they rely on calculating the liquidity (as a characteristic) for bonds, something that is very hard to do. The authors instead propose using an exchange-traded fund as a proxy, which can pinpoint differences in liquidity and be used to construct liquidity risk factors.

Some studies find that liquidity risk is not a large component of corporate bond returns, whereas other studies find it is strongly priced. One reason for the disparity is the time period being studied. The corporate bond market is "regime switching," alternating between "normal" and "stress," argue Acharya, Amihud, and Bharath (2010). They propose that in times of stress, the response to a liquidity shock is a flight to liquidity in the corporate bond market, with prices of investment-grade bonds rising and non-investment-grade bonds falling. During this stress regime, liquidity risk is strongly priced. During the "normal" regime, there is no corresponding flight to investment grade and liquidity is not as strongly priced. Liquidity risk is, therefore, time varying and dependent on which regime the economy is in. The authors have a practical risk management proposal of interest to practitioners. Though it is hard to measure the liquidity risk of an individual bond, investment-grade bonds generally do well during stress periods compared with non-investment-grade bonds. Therefore, managers worried about liquidity risk should consider diversifying their portfolios along these lines.

Hedge Funds. "Hedge fund" is an inclusive term describing a wide variety of strategies. Hedge funds are not homogeneous, but one commonality is relative illiquidity. As Black (2009) notes in his survey, hedge funds can have lockups - of one, two, or even three years - and also tend to invest in illiquid assets, whereas most mutual funds do neither. Hedge funds, therefore, have a unique liquidity profile.

Because hedge funds are opaque, it is hard for researchers to pinpoint the role liquidity plays in hedge fund returns, but there have been recent advances. Aragon (2007) finds a positive correlation between a lockup period and returns; in simplest terms, funds with a lockup period have higher returns than those without a lockup. He does not fully investigate what might be driving this correlation but argues that the lockup allows funds to invest efficiently in higher-performing illiquid assets. Moreover, in his study, the lockup is the source of the entire excess return of hedge funds: After controlling for lockup, Aragon finds that the average alpha of funds is negative.

In order to further investigate the role liquidity plays in hedge fund returns, Getmansky, Lo, and Makarov (2004) attempt to measure it more precisely. Their paper proceeds from the insight that hedge fund returns are highly serially correlated. They investigate and reject several possible explanations of this departure from the random walk before concluding that the serial correlation is tied to illiquidity. Part of the intuition behind their approach is that managers estimate the value of illiquid securities by linearly extrapolating from the most recent transaction price. This results in serial correlation and highly smoothed returns. They then test this hypothesis and create an economic model where serial correlation results from exposure to illiquid asset classes, as well as smoothing by managers. From this model, they are able to generate a new proxy measure for hedge fund illiquidity based on returns.

Khandani and Lo (2011) then use this measure to identify the component of hedge fund returns that results from liquidity premiums (or, in their language, "illiquidity premia"). They find that hedge funds that engage in convertible arbitrage and fixed-income arbitrage have the largest premiums attributable to liquidity effects, but managed futures, typically considered a relatively liquid strategy, also exhibit substantial illiquidity premiums. 
Furthermore, they find that these liquidity effects diminish over time (their sample period is 1996-2006) to near zero- the result, they argue, of increasing competition among hedge funds.

This serial correlation measure of hedge fund returns combines liquidity as a cost with liquidity as a risk. Other approaches to identifying liquidity's role in hedge fund returns try to decompose these two aspects of liquidity. For instance, Teo (2011) uses a Pástor-Stambaugh type of analysis to identify funds' liquidity risk in terms of exposure to systematic liquidity shocks. Sorting funds by this exposure shows that those with high liquidity risk outperform those with low liquidity risk by $5.8 \%$ per year. The larger focus of Teo's paper is to show that funds that take on high liquidity risk may also have favorable redemption terms. The substantial liquidity risk of these funds can result in an asset-liability mismatch in a crisis.

This research builds on Sadka (forthcoming), who, using his own liquidity measure, similarly investigates the liquidity risk of hedge funds. Sadka finds that liquidity risk, here defined as the covariation between a fund's return and a liquidity shock, indeed plays a significant role in hedge fund returns: Funds that loaded on liquidity risk outperformed funds with lower risk by $6 \%$ annually from 1994 to 2008. During the crisis, funds with greater liquidity risk underperformed. Moreover, he finds that liquidity risk varied by hedge fund investment style. For instance, it was high in convertible arbitrage, which is not surprising because a liquidity play is central to the strategy, which typically involves holding a long position in illiquid bonds and a short position in the underlying, more liquid stock. He finds the lowest liquidity exposure, and also the lowest returns, in the style "dedicated short bias."

The larger objective of Sadka's (forthcoming) research is to show that a fund's true liquidity risk is essentially independent of a fund's liquidity characteristics as seen in lockup periods. Investors' perceptions of a fund's liquidity are tied to the absence of a lockup period, but this is not necessarily related to the liquidity risk of the fund's assets. The author's ironic finding is that "the liquidity a fund provides to its investors need not necessarily reflect on the fund's exposure to aggregate liquidity variations" (p. 7).

Ang and Bollen (2010) propose a methodology for valuing the cost of lockups and notice periods for hedge funds. Their method could be of great practical use to hedge fund investors. Using real options theory, they estimate the implied cost of redemption restrictions. Their conclusion is that "hedge fund investors should be more concerned about the discretion asserted by fund managers in their partnership agreement, and conditions under which redemption suspensions can be imposed, rather than by the standard terms of lockup and notice periods" (p. 8).

Limitations/Summary. Investors should be aware that the idea that liquidity is priced is only a hypothesis. There are many counterexamples. For instance, Hasbrouck (2006), looking at the liquidity of stocks (as a characteristic), finds only extremely weak evidence that liquidity affected expected stock returns.

The returns from private equity provide a useful real-life example of liquidity or lack thereof not necessarily being priced. Lerner, Schoar, and Wongsunwai (2007) find that "average fund returns (net of fees) approximately equal the S\&P 500.” By any definition, private equity is much less liquid than the S\&P 500. The authors' results could be consistent with the idea that liquidity is priced, only here the general partners (fund operators) rather than the limited partners (outside investors) are harvesting the illiquidity premium. Or the results could stem from liquidity not being priced at all. Furthermore, Lerner et al.'s findings also point to the difference between expected returns and actual returns or between demand and supply - a distinction not often explored in the academic literature. Investors may demand higher expected returns for holding an illiquid asset class, but that does not mean that managers can necessarily supply it.

The concept of liquidity as a risk factor has been even more intensely questioned and is the subject of ongoing academic debate. For example, Lewellen, Nagel, and Shanken (2010) critique models that claim to have identified a new risk factor that should be priced in expected returns. Their skepticism includes liquidity as well as a long list of other candidates for priced risk factors, such as labor income and growth in GDP. The authors argue that asset pricing tests in all these instances use faulty empirical methods, in which the statistical hurdles for success are too low. Researchers have also had trouble replicating the results of liquidity risk models or finding significance 
using their own datasets. For example, Hu, Pan, and Wang (2010) "do not find a significant risk premium for the Pástor-Stambaugh equity liquidity risk factor using hedge fund returns as test portfolios” (p. 6).

Furthermore, there are inconsistencies in the methods used to calculate a liquidity beta, as well as inconsistent empirical results from different models all purporting to measure liquidity risk. Some find that illiquid stocks have higher liquidity risk - that is, illiquidity as a characteristic is closely correlated with liquidity as a risk-whereas others find no such relationship. Deeper questions remain about what is really meant by "liquidity risk" and whether liquidity risk is just a proxy for some other, currently unknown risk factor. The results of current academic attempts to replicate the results of liquidity risk models should shed light on this still controversial concept while generating heat among the disputants.

The ambiguity suffusing the field of liquidity and asset pricing, and the inconsistency of the results of different models, could stem from the ambiguity in the very concept of liquidity itself, which has no agreed-upon definition. Critically, market liquidity, the dimension of liquidity investigated by most asset pricing models, may be heavily influenced by funding liquidity (which is related to the amount of available arbitrage capital). Asset pricing models that do not also in some way incorporate or formally recognize the consequences of funding liquidity are thus often incomplete. The newer literature on funding liquidity is described in Part III of this survey.

Overall, though, the market liquidity and asset pricing literature is highly suggestive that liquidity, as either a cost or a risk, is priced and that lack of liquidity in an asset is associated with higher expected returns. Furthermore, investors may be paying for performance that is really a beta (exposure to liquidity risk) rather than an alpha reflecting managerial skill.

This higher expected return from illiquid assets can, in turn, influence portfolio choice, such that investors with longer time horizons are in a position to exploit these assets. By and large, the literature has not yet developed models of how to optimally do this-for instance, by incorporating the liquidity dimension into Merton-type life cycle models. In one rare paper, Ang, Papanikolaou, and Westerfield (2011) create a model for optimal portfolio choice with an illiquid asset. The model solves this allocation decision, and the authors find that the possibility of illiquid markets "causes the investor to behave in a more risk-averse manner with respect to both liquid and illiquid holdings" (p. 2).

Endowments solve the problem differently, of course, making substantial allocations to illiquid assets. Note that, as argued by Swensen (2000), the higher returns of such assets as private equity are not specifically a premium for holding illiquid assets; he argues that the payoffs are instead the result of a firm's research and management skills that can be implemented only when there are sufficiently long time horizons. Siegel (2008), in contrast, warns that high allocations to illiquid alternative investments "raise infrequently discussed concerns about liquidity" (p. 103).

The liquidity crisis of 2007 and beyond demonstrated the reality of these concerns; it showed that the endowment model, and asset allocation decisions in general, needs to more carefully consider the potential of market illiquidity and the inability to trade. Seemingly liquid markets can suddenly turn illiquid.

The following section of the review summarizes papers that model how markets can become illiquid. This question represents the next research thrust in the liquidity movement.

\section{Part II (Interlude): Liquidity and the 2007-09 Crisis}

The academic liquidity literature developed several models of financial fragility and the possibility of a liquidity crisis years before the actual 2007-09 crisis. These largely mathematical models in no way forecast an imminent crisis in the United States, but they were prescient in showing how a financial crisis might play out, if and when one occurred. They also raised the question of financial fragility at a time when the United States and the world were in the middle of the "great moderation" and the possibility of a systemic crisis was far from most investors' and regulators' minds.

This section of the review is really an interlude, introducing concepts that are treated at length in the following section: funding liquidity, systemic risk, and macro frictions (the long-term macro impact of a financial crisis and its rippling effects into the wider economy). This interlude discusses only papers tightly focused on liquidity after 
the initial shock of the crisis, rather than the voluminous economic literature about the overall crisis. Nonetheless, this sliver of research offers rigorous insights for understanding a liquidity crisis that are sometimes lacking in the larger, less formal literature.

Motivating papers for these new models of financial fragility and liquidity crises are those in the economic literature on bank runs, notably Diamond and Dybvig (1983) and Allen and Gale (1998). One distinction from traditional bank runs, according to the newer literature, is that the crisis occurred in the shadow banking system, rather than among retail depositors, with the exception of Northern Rock in the United Kingdom. To be more precise, this literature argues that the liquidity crisis, at least initially, was primarily a collateral run caused by dramatic changes to margins and "haircuts" on collateral used in the shadow banking system.

The new literature has also been spurred by the empirical episode of the Long-Term Capital Management (LTCM) crisis in 1998. Although a systemic meltdown was averted through a concerted intervention led by the Federal Reserve, LTCM showed the risks posed to the financial system by the failure of a large financial institution, even if it was not called a "bank."

Liquidity Spirals. A central paper in this new literature is Brunnermeier and Pedersen (2009), which models the links between market liquidity and the funding constraints facing financial intermediaries ("funding liquidity"). These links can give rise to liquidity spirals, which are negative feedback loops. (Work on the paper began in 2004, long before the crisis.) In Brunnermeier and Pedersen's model, a financial shock leads to an increase in traders' margin requirements, forcing them to delever. A continuous feedback loop develops. The authors dub this the "margin spiral," which they describe as follows: "A funding shock to speculators lowers market liquidity, leading to higher margins, which tightens speculators' funding constraints further, and so on" (p. 2205).

A second mechanism, which the authors (Brunnermeier and Pedersen 2009) call the "loss spiral," operates in tandem with the margin spiral. Here, the shock leads "to speculator losses on their initial position, forcing speculators to sell more, causing a further price drop, and so on" (p. 2205). These two spirals, jointly called "liquidity spirals," operate in tandem. In both instances, a small financial shock is greatly amplified, with sudden drops in market liquidity. The resulting equilibrium can be one of high margins and low liquidity. The presence of these destabilizing spirals accounts for the surprising fragility of liquidity.

Adrian and Shin (2008, 2010, 2011), in a complementary series of papers, focus on mark-to-market accounting as the primary mechanism through which a shock is transmitted, rather than endogenous margin requirements as in Brunnermeier and Pedersen (2009). Leverage plays a role as well. In essence, a decline in asset prices, caused by a financial shock, immediately affects the balance sheets of all banks holding the asset through mark-to-market accounting. In order to keep their leverage ratios within acceptable limits according to regulations, banks must sell assets, depressing prices further and, in turn, weakening balance sheets, leading to more selling, and so on. The authors use this feedback loop and its amplifying effects to explain why the relatively small subprime shock led to such a ferocious crisis.

Gorton (2010) and Gorton and Metrick (2011), in contrast, focus on uncertainty about the value of collateral as the key to understanding the initial crisis, as well as its surprising ferocity. Gorton's papers, many written during the unfolding of the crisis itself, detail the freezing of the repo market, which is at the heart of the shadow banking system. Repos, short for repurchase agreements, are an overnight deposit and lending market that is possibly larger than the traditional banking system. Lenders rely on collateral-largely, such securitized bonds as mortgagebacked or asset-backed securities - to secure their deposits. When doubts about the value of this collateral arose, haircuts spiked and ultimately the market froze. Gorton argues that the true systemic crisis was centered on the "run on the repo," with the first run occurring in August 2007, well before Lehman's collapse.

Acharya, Cooley, Richardson, and Walter (2010a) and Acharya and Richardson (2009) have written a series of papers that take a broader perspective on the liquidity crisis, locating it in the excessive tail risk taken by large complex financial institutions (LCFIs). The authors argue that the LCFIs engaged in regulatory arbitrage in 
response to government- and regulator-created distortions. This led them to take on tail risk while being inadequately capitalized in the event of a systemic crisis. When the crisis occurred, banks were left insolvent.

Acharya, Shin, and Yorulmazer (2011) further model banks' choices of liquidity. They find that banks' liquidity is countercyclical: During an economic upturn, return from risky assets is high and bank liquidity decreases. The reverse is true in a crisis. The authors write, "The most striking result here is that when liquidity in the market for external finance is low, for example, in business downturns or as crises become imminent, banks may hoard excessive liquidity" (p. 42). The question of why financial institutions would rely so heavily on shortterm financing-leaving them particularly vulnerable to a liquidity crisis—is further addressed by Brunnermeier and Oehmke (forthcoming). Their model shows that banks, in what the authors term a "maturity rat race," have incentives to rely on too much short-term debt, even if this leaves them exposed to rollover risk and bank runs.

Monetary Policy and Responses to the Crisis. Further papers by economists focused on liquidity explain why the traditional Fed responses to a financial crisis — such as an interest rate cut-are ineffective, or even counterproductive in the midst of an extreme liquidity crisis. In a provocative paper, Ashcroft, Gârleanu, and Pedersen (2010) show how interest rate cuts can worsen the situation. Reductions in interest rates potentially increase the shadow cost of capital because they increase the required return on high-haircut assets. Instead, reducing margin requirements (in the authors' language, lowering "haircuts") is a more effective tool to unfreeze markets because it reduces the shadow cost of capital. Beyond these technical arguments, the larger point of the paper is to show that in a severe liquidity crisis, the Fed may need to move beyond its traditional toolkit of interest rate cuts and use nontraditional monetary policy, such as direct interventions like the Term Asset-Backed Securities Loan Facility (TALF) program, to reassure and unlock frozen markets.

Further Readings. The literature focusing on the initial 2007-09 crisis from a liquidity perspective explains how liquidity spirals can arise, and more broadly, it demonstrates that institutions, particularly the institutional and regulatory structure of the shadow banking system, matter to the functioning of markets. Less clear in this literature is whether the episode was primarily a liquidity crisis or a solvency crisis; how to disentangle the two, as well as the appropriate policy response in each case, is not clearly articulated in the more recent literature.

Instead, the older banking literature (older here meaning 2005 and earlier) has more fully grappled with these issues. See, in particular, Diamond and Rajan (2005), who indicate how liquidity and solvency interact in a banking crisis. Shleifer and Vishny (1997) take an industry equilibrium view, with debt capacity as a central reference. Perhaps further integration of the more recent liquidity literature with the older bank-run literature (to which it is deeply indebted) will answer some of the questions about the true nature of the crisis, such as whether the Fed's new liquidity facilities were sufficient.

For longer, book-length accounts of the crisis and the fragility of the shadow banking system written by economists with a liquidity focus, see Gorton (2010) and Duffie (2011a). For a classic work on financial crises and how to manage them, see Bagehot's Lombard Street, ${ }^{2}$ which offers insights that are still relevant today.

\section{Part III: Funding Liquidity, Systemic Risk, and Macro Frictions}

This final section of this review drills down into ongoing, related areas of liquidity research: funding liquidity, systemic risk, and macro frictions. In general, this literature studies how demand/supply shocks in markets, including financial markets, can push prices away from fundamental values and why these markets do not automatically or immediately self-correct. It also offers insight into the macroeconomic and financial instability that follows a financial crisis.

"Funding liquidity" is the first topic discussed. In essence, the funding liquidity literature argues that financial shocks are propagated because financial institutions in charge of absorbing and correcting these shocks-market makers and the like-lack "funding liquidity." That is, they are constrained in their ability to borrow or otherwise

${ }^{2}$ Walter Bagehot, Lombard Street: A Description of the Money Market (London: Henry S. King and Co., 1873). 
raise capital. The crisis already discussed is one example of this situation. Dry-ups in funding liquidity and other financial frictions are key contributors to what is known as "systemic risk," which ripples across institutions and markets. The review looks at new methods for measuring this risk. The literature on "macro frictions," which combines macroeconomics with finance, is concerned with how constraints or "frictions" in the financial, labor, or other sectors affect the real economy (rather than just the financial system, as in funding liquidity models) and explores the ways in which a financial crash can lead to a persistent downturn in the real economy (outside the financial sector).

The boundaries between these topics are imprecise, but there are slight differences in emphasis between the real and financial sectors. However, they share one major commonality: The models for each are all similarly, though not identically, constructed, featuring a "financial accelerator" that magnifies a small financial shock. In all these models, the financial sector and frictions limiting the easy flow of credit play a central role.

Much of the work covered in this part of the review is at the research frontier and still very conceptual. However, there are also clear empirical results with asset pricing applications, as well as new ways of measuring systemic risk.

Funding Liquidity. Financial intermediaries - traditional market makers as well as broker/dealers, hedge funds, high-frequency traders, and the like-provide liquidity to markets. When these intermediaries' own funding is constrained, financial markets, and sometimes the whole economy, can run off course and become inefficient because arbitrageurs are no longer able to correct mispricing. Amplification effects involving a negative feedback loop between credit flows and asset prices can further drive prices away from fundamental value.

"Funding liquidity" is the common term used in the literature to describe the adequacy of capital or, alternatively, of constraints in funding faced by financial intermediaries. It was popularized by Brunnermeier and Pedersen in their 2009 paper; other researchers use similar concepts but never this terminology, referring instead to "collateral rates," "margins," "leverage," or simply "financial constraints" (Geanakoplos 1997). Perhaps the most accessible definition for funding liquidity is "amount of arbitrage capital available" (Hu, Pan, and Wang 2010, p. 1).

Funding liquidity is a very young subspecialty within liquidity research, as demonstrated by the preponderance of working papers as opposed to published journal articles on the topic. The agenda is wide ranging, identifying links between funding liquidity and market liquidity, the role of regulation, and the impact of funding liquidity on asset prices. One common theme is that funding constraints do not have to be binding to matter; the mere possibility that they could become binding is important to market makers and markets and may be reflected in asset prices.

Background. One paper underlying much of the funding liquidity literature is Grossman and Miller (1988), the same paper mentioned in the market liquidity section of the review. The authors point out that markets, such as the equity market, do not include only buyers and sellers but also feature financial intermediaries, or "market makers." Market makers fill the gaps between buyers and sellers and keep the market functioning. Their willingness to bear risk is crucial to this process. In short, the activities of market makers matter to the liquidity of markets.

Another motivating source for the recent funding liquidity literature is the corporate finance literatureparticularly, its discussion of financial constraints facing individual firms. These corporate finance frictions can include the ease of raising debt or equity. Holmström and Tirole's (2011) recent book on liquidity, which examines both the demand for and the supply of it, articulates these links to corporate finance theory, using insights from modern corporate finance "to study how such a theory can explain the pricing of assets, the role of liquidity management, [and] real investments” (p. 2).

A further influence on the funding liquidity literature comes from behavioral finance, particularly Shleifer and Vishny (1997), who pioneer the "limits of arbitrage" approach that is central to both behavioral finance and funding liquidity. They show that when "noise" (uninformed or irrational) traders drive market prices away from fundamental value, arbitrageurs may not be able to eliminate the mispricing because they face capital constraints. The arbitrageurs could run out of money when the market moves against them and be forced to liquidate their positions, driving the market even further away from fundamentals and amplifying the original mispricing. 
The behavioral literature - unlike the liquidity literature - is primarily focused on the behavioral biases that are the sources of these shocks. In contrast, the funding liquidity literature argues that investor irrationality is only one possible source of shocks. Instead, it could be that the shocks themselves are caused by constraints (financial, regulatory, or other) faced by financial institutions.

Funding Liquidity: Models. The financial amplification mechanism at the heart of funding liquidity models, as described by Sarkar and Shrader (2010), consists of "an initial shock [that] tightens funding constraints, causing the net worth of institutions to decrease and funding conditions to tighten further." A negative feedback loop ensues through different channels (depending on the model), including "higher margins, lower collateral value, lower asset market prices, and higher volatility," as well as through intermediaries' balance sheets. Whereas macro friction models focus on the effects of this feedback loop on the real economy, funding liquidity models focus on the effects on financial markets.

Of the many funding liquidity papers, this review discusses the few that are the most influential. (See the macro frictions section for largely parallel macro friction financial amplification papers focused on real variables.) Brunnermeier and Pedersen's (2009) funding liquidity paper, described in the previous section, models liquidity spirals and additionally shows how funding liquidity is linked to market liquidity via those spirals.

Another key paper is Gromb and Vayanos (2002). Their model features financial intermediaries ("arbitrageurs") who, through their trading, supply liquidity to markets, which they keep efficient by exploiting price discrepancies between similar assets. However, these arbitrageurs face financial constraints, which can at times lead to an exacerbation (rather than a correction) of a wedge in prices. What is noteworthy about the model is its focus on the welfare implications of these constraints. Gromb and Vayanos show that arbitrageurs can "fail to take a socially optimal level of risk" (p. 361). Put simply, arbitrageurs may put their capital at too much risk compared with what is socially optimal, a theme that has been evident in the crisis. (In addition to this welfare focus, there are technical differences from the Brunnermeier-Pedersen model: Brunnermeier and Pedersen [2009] feature endogenous margins and include multiple assets and markets. Also, the terminology is different: "funding liquidity" in Brunnermeier and Pedersen versus "financial constraints" in Gromb and Vayanos, even though the concepts are much the same.)

The Gromb and Vayanos (2002) model identifies the source of this suboptimal, excessive level of risk: Arbitrageurs do not internalize the externalities caused by their trades. A decline in arbitrageurs' capital during a crisis period can be "detrimental not only to other arbitrageurs but also to other investors" (p. 365) through the propagation of the crisis. The implications of this highly stylized model are that regulations changing arbitrageurs' financial constraints could be Pareto improving.

The welfare implications of financial amplification effects arising from financial intermediaries' funding constraints are also modeled by Korinek (2011). His model provides a theoretical framework indicating how to regulate this cycle. In Korinek's model (and in the real world), bankers will not provide enough liquidity during crisis periods, so capital injections could be mandatory during these periods. Alternatively, before a crisis, bankers do not insure against the risk of being financially constrained in the crisis. The reason for both actions is symmetrical: Bankers do not internalize the costs of the feedback loops they create. And this difficulty creates true welfare costs; the marketplace does not allocate resources efficiently because of the externalities imposed on it. The solution proposed by Korinek is to force bankers to internalize these costs through a Pigovian tax, analogous to taxes on pollution.

Funding Liquidity Meets Market Liquidity. Recent empirical papers, including market microstructure papers, further detail the mechanisms through which funding liquidity affects market liquidity and are also able to some degree to measure its impact.

Nagel (forthcoming) shows that in times of market stress, as indicated by changes in the Chicago Board Options Exchange Volatility Index (VIX), the supply of liquidity from market makers decreases and the expected return from liquidity provision increases. He uses profits from short-term reversal strategies (buying stocks that 
went down recently and selling stocks that went up) as a proxy for the expected returns from liquidity provision; these price reversals are indicative of inventory imbalances by market makers. He finds that during times of crisis, the inventory positions of market makers become strained so that liquidity is withdrawn, consistent with funding liquidity explanations. The author notes that increased risk aversion and increased uncertainty by market makers, however, are also plausible explanations for evaporating liquidity during market turmoil.

The implication of this paper is that price return reversals are thus predictable at times, leading to predictable profit opportunities. But this is the key feature of financial amplification models: Potential profits increase as the price wedge increases, but it is precisely at these times that arbitrageurs cannot exploit the profits because of funding constraints. In Nagel's (forthcoming) context, hedge funds pull out of markets in times of crisis and high volatility for risk management reasons. Countercyclical liquidity provision is profitable but not feasible for these hedge funds and similar market makers during times of crisis.

A persuasive market microstructure paper by Comerton-Forde, Hendershott, Jones, Moulton, and Seasholes (2010) provides empirical evidence that constraints on the funding capital of market makers affect asset market liquidity, as theorized by Gromb and Vayanos (2002) and Brunnermeier and Pedersen (2009) in their models described earlier. Moreover, this empirical paper is able to tease apart the various motives for the withdrawal of liquidity provision discussed by Nagel (forthcoming).

Comerton-Forde et al. (2010) analyze the balance sheets and income statements of New York Stock Exchange (NYSE) specialists (market makers), using proprietary data covering an 11-year period, and find that these variables explain stock market liquidity. As the authors point out, market makers "face short run limits on the amount of risk they can bear" (p. 296), with lenders imposing restraints on leverage ratios. When their inventory positions grow too large in any one direction, given these constraints, they are less willing to buy more inventory. The result is that spreads widen, which is synonymous with liquidity decreasing (recall that the size of the bidask spread is one measure of liquidity). And this is not true just for the stocks assigned to the afflicted specialist; there are spillover effects across the wider market. The authors find that "at both the aggregate level and the specialist firm level ... when specialists find themselves with larger positions or lose money on their inventories, effective spreads are significantly wider in the days that follow" (p. 325).

The Comerton-Forde et al. (2010) paper thus demonstrates that funding liquidity affects market liquidity not just during crisis periods but also on a day-to-day basis. Changes to the specialists' balance sheets and income statements show up in market liquidity in terms of spreads. The paper thus creates a new strand in the literature, integrating empirical market microstructure with funding liquidity theory. Future papers in this vein may consider the pricing implications of these dynamics.

Funding Liquidity: Asset Pricing. Much as the liquidity-adjusted CAPM posits that a security's expected return is increased by its market liquidity risk, the margin CAPM of Gârleanu and Pedersen (2011) links a security's expected return to its funding liquidity risk. That is, some securities are more highly exposed to the risk of a margin constraint becoming binding, which is reflected in the security's expected return.

Gârleanu and Pedersen (2011) write,

A stark illustration of this margin-based asset-pricing effect is the price difference between securities with the same cash flows but different margin requirements. We show that the required return on a high-margin security-e.g., a corporate bond - is greater than that of a low-margin security with the same cash flowse.g., proxied by a CDS. This is because of the high shadow cost of capital of the risk-tolerant investor. When the risk-tolerant investor's margin constraint binds, he is willing to accept a lower yield spread on a CDS, since it uses less margin capital. (p. 1983)

The implication of Gârleanu and Pedersen's margin CAPM — that securities with identical cash flows but different margins will have different prices-is a deviation from the law of one price. The authors empirically test this prediction among different assets, comparing corporate bonds with a CDS proxy, for instance, in which both securities have the same cash flow but different margin requirements. They find support for their model of 
margin-based asset pricing. During the crisis, high-margin securities had higher volatility and beta, even if they had cash flows identical to those of low-margin securities. (High-yield bonds have much higher margin requirements than CDS, according to this paper.)

One promising empirical strand of the funding liquidity literature examines how the risk-bearing capacity of the financial sector itself is reflected in asset pricing. As opposed to pure theory papers, these empirical papers find a correlation between broker/dealer balance sheets and returns from various asset classes, including equities, commodities, corporate and Treasury bond portfolios, and even foreign exchange. Adrian, Moench, and Shin (2010) and Adrian, Etula, and Muir (2010) document that "risky asset returns can largely be explained by their covariances with shocks to the aggregate leverage of broker-dealers" (Adrian, Etula, and Muir 2010), with balance sheets amplifying the initial shock. This strand of literature itself remains constrained by limited data about intermediaries' balance sheets, including hidden off-balance-sheet items. Nonetheless, it is remarkable for offering predictions about the relationship between funding liquidity and excess asset returns in an otherwise largely theoretical body of literature.

Discussion and Summary. Investors need to be aware that funding liquidity is only one source of market illiquidity. There are other drivers, perhaps more important ones, at least in non-crisis periods. These drivers include order flow imbalance, transaction costs, information asymmetries, search costs, problems finding a counterparty, and so forth. Nonetheless, the new funding liquidity literature is important. In addition to offering new insights about the crisis, it highlights the central role financial intermediaries play in the functioning of markets and the overall real economy.

Funding liquidity models, including those with a welfare focus, are a departure from classical frictionless finance, in which there is no need for welfare-improving policies because markets are already Pareto optimal. Among the interesting policy dilemmas posed by these new models is whether improved corporate governance on its own is enough to remedy excessive risk taking by banks. Better corporate governance can better align managers' incentives with those of shareholders, but the incentives of both may diverge from what improves society's welfare on the whole because banks do not internalize the externalities they impose, such as not supplying liquidity during a crisis. The welfare strand of the funding liquidity literature is, at this point, still too stylized to offer precise policy prescriptions for the funding liquidity problems of financial intermediaries. It cannot say, for example, whether the government should have bailed out Lehman Brothers. But the literature does introduce a framework that can begin to address these sorts of questions.

Measuring Systemic Risk. Systemic risk, like so many concepts in the liquidity and liquidity-related literature, is difficult to define. Taylor (2009), after reviewing research on systemic risk, concludes that "there is no clear operational definition and measure of systemic risk" (p. 9). He also points out that he is not alone in his assessment; the International Monetary Fund (IMF), the Bank for International Settlements (BIS), and the Financial Stability Board (FSB) were similarly unable to reach an operational definition of systemic risk.

More recently, a consensus about how to at least define (if not measure) systemic risk has begun to emerge. The IMF-BIS-FSB (2009) report "Guidance to Assess the Systemic Importance of Financial Institutions, Markets and Instruments: Initial Considerations" defines systemic risk as "the risk of disruption to financial services that results from an impairment of all or part of the financial system and that has the potential to have negative consequences for the real economy" (p. 2). This concept is broader than a liquidity crisis, although a drying up of liquidity is certainly an aspect of this system-wide collapse.

Measuring the threat of systemic risk is even harder than defining it. Conventional financial risk measures like value at risk $(\mathrm{VaR})$ are limited by the fact that they measure the risk of an institution in isolation; they do not measure the risks facing the financial system as a whole, nor do they capture the threat to the stability of the financial system posed by the externalities stemming from a failure of a financial institution.

Since the crisis, liquidity researchers have developed new measures aimed at capturing systemic risks. Many proceed from the classification laid out by Brunnermeier, Crocket, Goodhart, Persaud, and Shin (2009) and 
further interpreted by Adrian and Brunnermeier (2011) positing that "a systemic risk measure should identify the risk on the system by individually systemic institutions, which are so interconnected and large that they can cause negative risk spillover effects on others, as well as by institutions that are systemic as part of a herd" (Adrian and Brunnermeier 2011, p. 1).

These new measures, therefore, largely identify the systemic risk contributions of individual institutions. Less common in the literature are measures that instead try to capture risks that are flowing throughout the financial system itself, whether or not they could cause individual firms to fail. Additionally, the literature is primarily written from a supervisory perspective, taking a first step toward more macro-prudential regulation of institutions that contribute to systemic risk; however, many of the measures could be useful to investors as well, allowing them to identify the stability of their counterparties in the event of a crisis, as well as to inform them of broader stresses facing the financial system.

In terms of methodology, the systemic risk measurement literature focused on institutions can be divided into papers that take a "contingent claims analysis" approach derived from option pricing theory, such as Gray, Merton, and Bodie (2008) and Gray and Jobst (2010), and those that take a "reduced form" approach, focusing on the statistical tail behavior of an institution's asset returns. This second approach is taken by most of the papers described next.

Measures. CoVaR, developed by Adrian and Brunnermeier (2011, with earlier versions), is one of the first systemic risk measures to emerge post-crisis and measures the $\mathrm{VaR}$ of the whole financial sector conditional upon an individual institution being in distress. The "Co" in CoVaR is short for "conditional, contagion, or contributing," all words emphasizing the systemic nature of the authors' approach and its measurement of externalities and comovement among financial institutions. The authors calculate CoVaR using quantile regressions. They estimate which institutions contribute the most to systemic risk as well as which are most exposed in times of financial distress.

The NYU Stern Systemic Risk Rankings, a systemic risk measure developed by Acharya, Pedersen, Philippon, and Richardson (2010), avoid the shortcomings inherent in a VaR approach (discussed later) by using the "expected shortfall" approach instead. In essence, the measure reveals the expected losses of equity investors in specific financial institutions if there is a massive market decline. These firms will face the greatest capital shortfall in the event of a crisis and, hence, pose the greatest threat to systemic stability. The authors empirically test their measure by looking at firms' performances in stress tests in 2009 as well as firms' performances during the crisis period of 2007-2008. Their conclusion is marginal expected shortfall (MES), which they define as "the average return of each firm during the $5 \%$ worst days for the market" (p. 4), appears to be able to predict the financial firms with the worst contributions in the systemic crisis.

Brownlees and Engle (2011) estimate MES using advanced time-series methods. Their results, which rank firms by MES, show that highly leveraged firms, large firms, and firms with a high exposure to systemic risk have higher levels of MES. Not surprisingly, highly leveraged, very large banks are at the top of their rankings, as are some insurance companies. They conclude that the most systemically risky sector is broker/dealers.

The NYU MES measure is limited to publicly traded companies; it is based on public market data and the prediction of how much the stock of a particular financial company will decline if the whole market declines. Nonpublicly traded institutions, such as large hedge funds, are thus not included. Billio, Getmansky, Lo, and Pelizzon (2010) take an approach that includes private hedge funds in addition to publicly listed entities in their analysis of systemic risk in the finance and insurance sectors. They propose five different measures to capture different aspects of systemic risk - notably, liquidity, leverage, linkages, and losses, which can give rise to a severe dislocation. Among the authors' contributions is an illiquidity measure for key financial sectors based on autocorrelations, an insight previously used by Getmansky, Lo, and Makarov (2004) to measure the liquidity of individual hedge funds. The authors find that the financial and insurance sectors have become "highly interrelated and less liquid over the past decade, increasing the level of systemic risk." They conclude that the primary repository of systemic risk in the United States was not the hedge fund sector but, instead, banks that took hedge fund-type risks. They dub these banks "shadow hedge funds." 
Also taking a broad approach are Sullivan, Peterson, and Waltenbaugh (2010), whose model is predictive in spirit rather than primarily regulatory like $\mathrm{CoVaR}$. The paper describes extreme value theory and indicates why there was increased downside tail risk in the recent crisis, in contrast to Gaussian distributions used in VaR models, which, as the authors note, "tend to underweight extreme values" (p. 11). They then model variables (factors) that predict this increase in tails - movements in market volatility, liquidity, and credit risk - using a logistic regression. The resulting systemic risk indicator offers investors a clear framework for monitoring the risks of a systemic "event": the failure of multiple asset classes on a single day.

Borio and Drehmann (2009a) distinguish contemporaneous and leading indicators of financial stress. Many of the systemic risk measures, such as MES, are contemporaneous indicators, which spike once stress materializes. Borio and Drehmann further develop a tool based on deviations of aggregate asset prices and the credit-to-GDP ratio from long-term trends. (A similar method is used by Fitch Ratings for country ratings.) The method is relevant from a policy perspective because deviations of the credit-to-GDP ratio from its long-term trend form the starting point for setting countercyclical capital buffers for banks. Borio and Drehmann argue that their indicator would have signaled a buildup of systemic risk two to three years before the 2007 crisis.

New Reporting Requirements. Several policy papers have proposed that financial institutions be subject to new reporting requirements to directly identify systemic risks; the underlying argument is that regulators have not been collecting the data needed to see the next crisis coming. Also, market-based systemic risk indicators are clouded by the fact that they implicitly incorporate the likelihood of a government reaction to a crisis and the effect of this intervention; they do not cleanly indicate the likelihood of a crisis alone. Hence, these papers argue that there is a need for new reporting processes to warn of systemic risk.

Duffie (2011b) has a straightforward proposal for monitoring systemic risk, which he calls "10 by 10 by $10 . "$ A risk regulator would require each systematically important firm to report its gain and loss, and those of its counterparties, to 10 different stresses. Some of this information would be released to the public. Duffie argues, "The joint exposure of the system to particular stress tests and particular entities (or chains of entities) could as a result be clarified" (p. 3). Brunnermeier, Gorton, and Krishnamurthy (2011) propose a similar but even more comprehensive data acquisition and dissemination process to provide information about systemic risk to regulators and investors. The implementation of either proposal (both of which await regulator buy-in) could, according to Brunnermeier et al., lead to better pricing and management of systemic risk, alerting regulators and the public to the buildup of risks before they materialize in another full-blown crisis.

Summary and Conclusions. Addressing financial instability and measuring systemic risk are clearly policy priorities. Nonetheless, Borio and Drehmann (2009b) note that "despite the efforts made, policymakers are still a long way from developing a satisfactory operational framework. A major challenge complicating this task is the 'fuzziness' with which financial (in)stability can be measured" (p. iii). Adding to the confusion is the concern that some systemic risk measures are leading while others are contemporaneous; some focus on individual institutions while others focus on the entire financial system. Finally, measures that are regulatory in spirit and use existing market data are clouded by the fact that these data also incorporate anticipated regulatory response. And of course, the definition of systemic risk itself remains fuzzy.

Notwithstanding, there has been rapid progress in developing the new systemic risk measures already described, with further impetus provided by the Dodd-Frank Act, which requires the Fed to identify systemically important financial institutions. Additional clarity in measuring systemic risk may come from improved reporting of data in tandem with macro-prudential regulation and, in particular, a better knowledge of flow of funds and exposures of various financial institutions. In terms of further reading, the IMF's 2011 "Global Financial Stability Report" ${ }^{3}$ contains a useful summary of various approaches to measuring and controlling systemic liquidity risk, with a particular focus on the likely impact of Basel III rules.

${ }^{3}$ IMF, “Global Financial Stability Report,” International Monetary Fund (April 2011): www.imf.org/external/pubs/ft/gfsr. 
Financial Frictions and Macroeconomic Modeling. Standard macroeconomic models, known as dynamic stochastic general equilibrium (DSGE) models, assume away such financial frictions as liquidity events. Even worse, they have no role, or certainly no special role, for the financial sector; if financial intermediaries exist in these models, they are treated as merely a "veil" over real activity. Instead, these models are based on representative agents who invest directly.

The limitations and even possible irrelevance of these general equilibrium models, which define no role for banks, were made clear by the credit crisis. The standard model was unable to predict the crisis or provide guidance on how the real economy would be affected. Central banks, to the extent that they used these models, similarly lacked a playbook. For an overview of the strengths and weaknesses of DSGE models written from a central banking perspective, see the BIS working paper "DSGE Models and Central Banks" (Tovar 2008).

Incorporating financial frictions into standard macroeconomic models is immensely challenging. It means moving beyond representative agents to include heterogeneous agents, leverage, and a role for financial intermediaries, as well as linking the financial sector to the real economy. Most challenging of all, it means modeling endogenous risks stemming from the financial sector itself and Minsky-type effects where a boom sows the seeds for a bust.

Several general equilibrium macro models have been able to incorporate financial frictions. The first generation of models in a rapidly growing theoretical literature includes, most prominently, Bernanke, Gertler, and Gilchrist (1999, usually referred to in the literature as BGG), Bernanke and Gertler (1989), Geanakoplos (1997), and Kiyotaki and Moore (1997). These authors identify how a small short-term shock can be amplified into persistent fluctuations in the larger economy through a "financial accelerator" consisting of adverse credit and financial conditions. The amplification occurs because of leverage in the financial system and feedback effects through prices. These responses lead to endogenous risk.

Although these authors identify how credit constraints on borrowers can amplify a shock, financial intermediaries are still not central to these models. For instance, in Kiyotaki and Moore's (1997) highly abstract model, which is focused on the value of collateral, there are no "banks." Agents can be only "farmers" or "gatherers." There are no disruptions to financial intermediaries, only to borrowers' balance sheets. Also, on a technical note, these authors solve for system dynamics using log-linear approximations around a steady state, which determines what sort of results come from these models.

More recent macro friction models give financial intermediaries a more central role. These papers include Gertler and Kiyotaki (2010), He and Krishnamurthy (2010), and Brunnermeier and Sannikov (2012). Similar papers by Cúrdia and Woodford (2009) and Gertler and Karadi (2011) add monetary policy to their frameworks.

The Brunnermeier and Sannikov (2012) model, for instance, features a financial sector, heterogeneous agents, and leverage. What sets it apart from most other friction models is its solution method. The authors use a nonlinear solution rather than log-linear approximations around a steady state. This new approach, uncommon in macroeconomics, leads to new results. The authors write,

The stochastic steady state is defined as the balance point to which the system tends to come back after it is hit by small shocks. ... The most important phenomena occur when the system is knocked off balance away from the steady state. The full characterization of system dynamics allows us to derive a number of important implications. (p. 2)

Previous macro friction models, such as Kiyotaki and Moore (1997), show how following a small shock, even if there are amplifications or deviations, the economy is eventually pulled back to stability. This stable outcome is the result of the log-linear solution method. Kiyotaki and Moore admit this (in a footnote): "We shall be concerned with characterizing the equilibrium path that converges back to the steady state" (p. 215).

In contrast, the outcome of the Brunnermeier and Sannikov (2012) model, using nonlinear dynamics, is an economy that is prone to instability. If there is a large enough shock, it can go from a normal regime to a crisis regime. Rather than finding a way back to the steady state, the economy can remain in a crisis state for a long period of time. And in the crisis state, volatility spikes and asset prices become more correlated. 
This highly abstract model, therefore, has results consistent with conditions in the real world during a crisis. (However, the model still does not capture Minsky moments where there is a sudden regime shift. In the model, the switch from stable to crisis regimes is gradual.)

Limitations/Summary. Macro friction models (and recent world events) show how a financial shock can be uniquely destabilizing, leading to long-lasting and persistent aftereffects afflicting the real economy. Such models as that of Brunnermeier and Sannikov (2012) — though incomplete, lacking a labor sector or a developed role for monetary policy-are helpful in thinking about these issues in macro finance. Most importantly, they may someday be able to provide tighter policy advice. This could mean setting capital requirements for banks based on precise quantitative predictions about systemic risk or the potential macroeconomic fallout, rather than just intuition or political wrangling. The models could also suggest appropriate monetary and regulatory policies to avoid future bubbles and crashes, as well as ways for the economy to recover most quickly given the liquidity frictions that occur after a crash.

This review has primarily focused on DSGE models; for a comprehensive survey of all macro models that include financial friction, see Brunnermeier, Eisenbach, and Sannikov (2011). For complementary empirical studies about the aftermath of a financial crisis, see the pioneering empirical papers and books of Reinhart and Reinhart (2010) and Reinhart and Rogoff (2009).

Conclusion. The new wave of research into liquidity, documented in this literature review, will perhaps culminate in ways to better regulate the financial system, to increase macrostability, and to decrease the threat of systemic risk and liquidity events. Specific calls for reform are beyond the scope of this review. Nonetheless, for suggested reforms to improve macrostability written by economists with a liquidity background, see the books by Acharya, Richardson, van Nieuwerburgh, and White (2011) and Acharya, Cooley, Richardson, and Walter (2010b). Also, the 2011 IMF publication “Global Financial Stability Report," mentioned in the systemic risk part of the review, proposes various macro-prudential measures to reduce liquidity risk.

Overall, this review has attempted to show that although liquidity does not have a single consistent definition or meaning, it remains critically important, albeit in different contexts. In Part I, on liquidity and asset pricing, the literature largely takes the organization of markets as a given and asks if liquidity is priced. The more recent literature, described in Parts II and III, focuses on the institutional setup that can create liquidity frictions and on the macro impact of these frictions. The general message of this research is that shocks to the financial system, through various amplification mechanisms, can lead to persistent departures from fundamental values. Sovereign credit risk and possible default may be the ultimate outcome of the liquidity crisis. Acharya, Drechsler, and Schnabl (2011) map out this chain of events, chronicling the "intimate" links between bank bailouts and sovereign credit risk.

Real-life events have unfortunately kept pace with the idea, emphasized in the liquidity literature, of amplification of an initial financial shock. The liquidity crisis was unlike a conventional shock, such as the piercing of the dot-com bubble, which resulted in only a conventional kind and degree of fallout. Instead, because it involved the financial sector, the latest crisis has had poisonous aftereffects on the real economy. The sovereign debt crisis is the most recent chapter in an unfolding story of gloom. One cause for optimism is the continuing advances in the understanding of liquidity. Moreover, policies based on this understanding could mitigate future liquidity crises. 


\section{BIBLIOGRAPHY}

Acharya, Viral V., and L.H. Pedersen. 2005. "Asset Pricing with Liquidity Risk.” Journal of Financial Economics, vol. 77 , no. 2 (August):375-410.

"This paper studies equilibrium asset pricing with liquidity risk - the risk arising from unpredictable changes in liquidity over time. We derive explicitly a liquidity-adjusted capital asset pricing model. A security's required return is shown to depend on its expected illiquidity and on the covariances of its own return and illiquidity with market return and market illiquidity. Further, if a security's liquidity is persistent, a shock to its illiquidity results in low contemporaneous returns and high predicted future returns." (p. 375)

Acharya, Viral V., and M. Richardson. 2009. "Causes of the Financial Crisis.” Critical Revierw, vol. 21, no. 23:195-210.

"Why did the popping of the housing bubble bring the financial system-rather than just the housing sector of the economy - to its knees? The answer lies in two methods by which banks had evaded regulatory capital requirements. First, they had temporarily placed assets-such as securitized mortgages - in off-balance-sheet entities, so that they did not have to hold significant capital buffers against them. Second, the capital regulations also allowed banks to reduce the amount of capital they held against assets that remained on their balance sheets-if those assets took the form of AAA-rated tranches of securitized mortgages. ... The principal effect of this regulatory arbitrage, however, was to concentrate the risk of mortgage defaults in the banks and render them insolvent when the housing bubble popped." (p. 195)

Acharya, Viral V., Yakov Amihud, and Sreedhar T. Bharath. 2010. “Liquidity Risk of Corporate Bond Returns.” NBER Working Paper No. 16394 (September).

"We study the exposure of the U.S. corporate bond returns to liquidity shocks of stocks and Treasury bonds over the period 1973 to 2007. A decline in liquidity of stocks or Treasury bonds produces conflicting effects: Prices of investment-grade bonds rise while prices of speculative grade bonds fall substantially. Our findings suggest the existence of time-varying liquidity risk of corporate bond returns and episodes of flight to liquidity." (p. 1)

Acharya, Viral V., Itamar Drechsler, and Philipp Schnabl. 2011. "A Pyrrhic Victory? - Bank Bailouts and Sovereign Credit Risk.” NBER Working Paper No. 17136 (June).

"The authors show that financial sector bailouts and sovereign credit risk are intimately linked. A bailout benefits the economy by ameliorating the under-investment problem of the financial sector. However ... the sovereign may choose to fund the bailout by diluting existing government bondholders, resulting in a deterioration of the sovereign's creditworthiness. This deterioration feeds back onto the financial sector, reducing the value of its guarantees and existing bond holdings and increasing its sensitivity to future sovereign shocks." (p. 1)

Acharya, Viral V., Hyun Song Shin, and Tanju Yorulmazer. 2011. "Crisis Resolution and Bank Liquidity.” Review of Financial Studies, vol. 24, no. 6 (June):2166-2205.

"What is the effect of financial crises and their resolution on banks' choice of liquidity? When banks have relative expertise in employing risky assets, the market for these assets clears only at fire-sale prices following a large number of bank failures. The gains from acquiring assets at fire-sale prices make it attractive for banks to hold liquid assets. The resulting choice of bank liquidity is countercyclical, inefficiently low during economic booms but excessively high during crises.” (p. 2166) 
Acharya, Viral V., Thomas Cooley, Matthew Richardson, and Ingo Walter. 2010a. "Manufacturing Tail Risk: A Perspective on the Financial Crisis of 2007-09." Foundations and Trends in Finance, vol. 4, no. 4:247-325.

"We argue that the fundamental cause of the financial crisis of 2007-09 was that large, complex financial institutions ('LCFIs') took excessive leverage in the form of manufacturing tail risks that were systemic in nature and inadequately capitalized. . . . We conclude that several principal imperfections, in particular, distortions induced by regulation and government guarantees, developed in decades preceding the current one, allowing LCFIs to take on excessive systemic risk.” (p. 247)

\section{- eds. 2010b. Regulating Wall Street: The Dodd-Frank Act and the Nerw Architecture of Global Finance.} Hoboken, NJ: John Wiley \& Sons.

This book by NYU financial economists assesses the strengths and weaknesses of the Dodd-Frank Act and its implications for the future of the U.S. as well as the global financial system.

Acharya, Viral V., Lasse H. Pedersen, Thomas Philippon, and Matthew Richardson. 2010. "Measuring Systemic Risk.” Working paper, New York University (March).

"We present a simple model of systemic risk and we show that each financial institution's contribution to systemic risk can be measured as its systemic expected shortfall (SES), i.e., its propensity to be undercapitalized when the system as a whole is undercapitalized. SES increases with the institution's leverage and with its expected loss in the tail of the system's loss distribution." (p. 1)

Acharya, Viral V., Matthew Richardson, Stijn van Nieuwerburgh, and Lawrence J. White. 2011. Guaranteed to Fail: Fannie Mae, Freddie Mac and the Debacle of Mortgage Finance. Princeton, NJ: Princeton University Press.

This book, by four NYU academics, is a rigorous analysis of the failures of the GSEs. It offers proposals for mortgage reform in the United States, including an assessment of plans from the Obama administration.

Adrian, Tobias, and Markus K. Brunnermeier. 2011. “CoVaR.” NBER Working Paper No. 17454 (October).

"We propose a measure for systemic risk: $\mathrm{CoVaR}$, the value at risk $(\mathrm{VaR})$ of the financial system conditional on institutions being in distress. We define an institution's contribution to systemic risk as the difference between $\mathrm{CoVaR}$ conditional on the institution being in distress and $\mathrm{CoVaR}$ in the median state of the institution. From our estimates of CoVaR for the universe of publicly traded financial institutions, we quantify the extent to which characteristics such as leverage, size, and maturity mismatch predict systemic risk contribution." (p. 1)

Adrian, Tobias, and Hyun Song Shin. 2008. "Liquidity and Financial Contagion." Banque de France's Financial Stability Review, no. 11 (February, Special Issue on Liquidity):1-7.

This short and clear paper demonstrates that financial contagion, rather than occurring through a series of defaults, can spread through price changes of marked-to-market capital of financial institutions.

-2010. "The Changing Nature of Financial Intermediation and the Financial Crisis of 2007-2009." Annual Review of Economics, vol. 2 (September):603-618.

"The financial crisis of 2007-09 highlighted the changing role of financial institutions and the growing importance of the 'shadow banking system,' which grew out of the securitization of assets and the integration of banking with capital market developments. This trend was most pronounced in the United States, but it also had a profound influence on the global financial system as a whole. The authors describe the changing nature of financial intermediation in the market-based financial system, chart the course of the recent financial crisis, and outline the policy responses that have been implemented by the Federal Reserve and other central banks." (p. 603) 
- 2011. "Financial Intermediary Balance Sheet Management." Annual Review of Financial Economics, vol. 3 (December):289-307.

"Conventional discussions of balance sheet management by nonfinancial firms take the set of positive net present value (NPV) projects as given, which in turn determines the size of the assets of the firm. ... In contrast, the balance sheet management of financial intermediaries reveals that it is equity that behaves like the pre-determined variable, and the asset size of the bank or financial intermediary is determined by the degree of leverage that is permitted by market conditions. . . . We further explore the aggregate consequences of such behavior by the banking sector for the propagation of the financial cycle and securitization.” (Introduction)

Adrian, Tobias, Erkko Etula, and Tyler Muir. 2010. "Financial Intermediaries and the Cross-Section of Asset Returns.” Federal Reserve Bank of New York Staff Report 464 (July).

"We document that risky asset returns can largely be explained by their covariances with shocks to the aggregate leverage of security broker-dealers. Our findings indicate that broker-dealer leverage is a valid representation of the stochastic discount factor, an interpretation consistent with recent intermediary asset pricing theories."

Adrian, Tobias, Emanuel Moench, and Hyun Song Shin. 2010. "Financial Intermediation, Asset Prices, and Balance Sheet Quantities." IMF Economic Revierw, vol. 58, no. 1 (September):179-207.

"Fluctuations in the aggregate balance sheets of financial intermediaries provide a window on the joint determination of asset prices and macroeconomic aggregates. We document that financial intermediary balance sheets contain strong predictive power for future excess returns on a broad set of equity, corporate, and Treasury bond portfolios. We also show that the same intermediary variables that predict excess returns forecast real economic activity and various measures of inflation. Our findings point to the importance of financing frictions in macroeconomic dynamics and provide quantitative guidance for preemptive macroprudential and monetary policies.”

Allen, Franklin, and Douglas Gale. 1998. "Optimal Financial Crises.” Journal of Finance, vol. 53, no. 4 (August):1245-1284.

"Empirical evidence suggests that banking panics are a natural outgrowth of the business cycle. In other words panics are not simply the result of 'sunspots' or self-fulfilling prophecies. Panics occur when depositors perceive that the returns on the bank's assets are going to be unusually low. In this paper we develop a simple model of this type of panic. In this setting bank runs can be incentiveefficient: they allow more efficient risk sharing between depositors who withdraw early and those who withdraw late and they allow banks to hold more efficient portfolios. Central bank intervention to eliminate panics can lower the welfare of depositors. However there is a role for the central bank to prevent costly liquidation of real assets by injecting money into the banking system during a panic." (p. 1245)

Amihud, Yakov. 2002. "Illiquidity and Stock Returns: Cross-Section and Time-Series Effects." Journal of Financial Markets, vol. 5, no. 1 (January):31-56.

"This paper shows that over time, expected market illiquidity positively affects ex ante stock excess return, suggesting that expected stock excess return partly represents an illiquidity premium. This complements the cross-sectional positive return-illiquidity relationship. . . . Illiquidity affects more strongly small firm stocks, thus explaining time series variations in their premiums." (p. 31) 
Amihud, Yakov, and Haim Mendelson. 1986. “Asset Pricing and the Bid-Ask Spread.” Journal of Financial Economics, vol. 17, no. 2 (December):223-249.

"This paper studies the effect of the bid-ask spread on asset pricing. We analyze a model in which investors with different expected holding periods trade assets with different relative spreads. The resulting testable hypothesis is that market-observed expected return is an increasing and concave function of the spread.” (p. 223)

—. 1991. "Liquidity, Maturity, and the Yields on U.S. Treasury Securities." Journal of Finance, vol. 46, no. 4 (September):1411-1425.

The authors compare the yields to maturity on comparable Treasury notes and bills of matched maturity. Notes have lower liquidity and higher yields, a confirmation of the effects of liquidity in asset pricing.

Amihud, Yakov, Haim Mendelson, and Lasse H. Pedersen. 2005. "Liquidity and Asset Prices." Foundations and Trends in Finance, vol. 1, no. 4:269-364.

This extensive survey reviews how liquidity affects the required return of assets. It discusses both theory and empirical results of liquidity-based asset pricing models and finds that liquidity can play an important role in solving many puzzles in asset pricing, including the equity premium puzzle.

Ang, Andrew, and Nicolas P.B. Bollen. 2010. "Locked Up by a Lockup: Valuing Liquidity as a Real Option.” Financial Management, vol. 39, no. 3 (Autumn):1069-1096.

"Hedge funds often impose lockups and notice periods to limit the ability of investors to withdraw capital. We model the investor's decision to withdraw capital as a real option and treat lockups and notice periods as exercise restrictions. ... The cost of illiquidity can easily exceed $10 \%$ if the hedge fund manager suspends withdrawals.” (p. 1069)

Ang, Andrew, Dimitris Papanikolaou, and Mark M. Westerfield. 2011. "Portfolio Choice with Illiquid Assets." Working paper, Columbia University (May).

"We investigate how the inability to continuously trade an asset affects portfolio choice. We extend the standard model of portfolio choice to include an illiquid asset which can only be traded at infrequent, stochastic intervals. Because investors cannot insure against the inability to trade, illiquidity induces endogenous additional time varying risk aversion above the curvature in their utility functions."

Aragon, George O. 2007. "Share Restrictions and Asset Pricing: Evidence from the Hedge Fund Industry." Journal of Financial Economics, vol. 83, no. 1 (January):33-58.

This paper finds that hedge funds with lockup restrictions have excess annual returns of 4-7\% compared with funds without lockups, an example of higher expected returns for comparatively illiquid assets.

Ashcroft, Adam, Nicolae Gârleanu, and Lasse Heje Pedersen. 2010. "Two Monetary Tools: Interest Rates and Haircuts." NBER Macroeconomics Annual, vol. 25, no. 1:143-180.

"This paper studies the links between haircuts, required returns, and real activity, and evaluates the different monetary policy tools theoretically and empirically. The authors show that binding constraints increase required returns and propagate business cycles. The central bank policy of reducing the interest rate decreases the required returns of low-haircut assets but may increase those of highhaircut assets, since it may increase the shadow cost of capital for constrained agents. A reduction in the haircut of an asset unambiguously lowers its required return and can ease the funding constraints on all assets." (pp. 143-144) 
Bernanke, Ben, and Mark Gertler. 1989. “Agency Costs, Net Worth, and Business Fluctuations.” American Economic Review, vol. 79, no. 1 (March):14-31.

"This paper develops a simple neoclassical model of the business cycle in which the condition of borrowers' balance sheets is a source of output dynamics. The mechanism is that higher borrower net worth reduces the agency costs of financing real capital investments. Business upturns improve net worth, lower agency costs, and increase investment, which amplifies the upturn; vice versa, for downturns. Shocks that affect net worth (as in a debt-deflation) can initiate fluctuations." (p. 14)

Bernanke, Ben S., Mark Gertler, and Simon Gilchrist. 1999. “The Financial Accelerator in a Quantitative Business Cycle Framework." In Handbook of Macroeconomics, vol. 1C. Edited by John B. Taylor and Michael Woodford. Oxford, U.K.: Elsevier.

"This paper develops a dynamic general equilibrium model that is intended to help clarify the role of credit market frictions in business fluctuations, from both a qualitative and a quantitative standpoint. ... The framework exhibits a financial accelerator, in that endogenous developments in credit markets work to amplify and propagate shocks to the macroeconomy. . . Under reasonable parametrizations of the model, the financial accelerator has a significant influence on business cycle dynamics." (p. 1341)

Billio, Monica, Mila Getmansky, Andrew W. Lo, and Loriana Pelizzon. 2010. "Measuring Systemic Risk in the Finance and Insurance Sectors." Working paper, MIT (March).

"In this paper, we propose five measures of systemic risk based on statistical relations among the market returns of ... four types of financial institutions. Using correlations, cross-autocorrelations, principal components analysis, regime-switching models, and Granger causality tests, we find that all four sectors have become highly interrelated and less liquid over the past decade, increasing the level of systemic risk in the finance and insurance industries.”

Black, Keith H. 2009. "Investing in Hedge Funds: A Survey.” Research Foundation of CFA Institute Literature Review (April).

"Although the media and many investors perceive hedge funds to be uniformly risky, the facts are that little about the hedge fund universe is homogenous. Some hedge funds hedge, whereas others take directional market risks. As a result of the private and opaque nature of hedge fund investing, a multitude of data challenges exist because hedge funds are not required to report their returns to regulators or any single database. Much of the literature describes adjustments and caveats to working with as-reported hedge fund returns and risk data." (p. 1)

Bongaerts, Dion, Frank de Jong, and Joost Driessen. 2011. "An Asset Pricing Approach to Liquidity Effects in Corporate Bond Markets.” Working paper, Fisher College of Business (May): https://fisher.osu.edu/blogs/ efa2011/files/APE_5_1.pdf.

"We use an asset pricing approach to compare the effects of expected liquidity and liquidity risk on U.S. corporate bond prices, and to assess whether liquidity effects can explain the credit spread puzzle. Liquidity measures are constructed for bond portfolios using a Bayesian approach to estimate Roll's effective cost measure. We find strong evidence that expected liquidity affects expected bond returns. In contrast, using various measures for liquidity risk we find no evidence for a liquidity risk premium.”

Borio, Claudio, and Matthias Drehmann. 2009a. “Assessing the Risk of Banking Crises - Revisited.” BIS Quarterly Review (March).

"Historically, unusually strong increases in credit and asset prices have tended to precede banking crises. Could the current crisis have been anticipated by exploiting this relationship? We explore this 
question by assessing the out-of-sample performance of leading indicators of banking system distress developed in previous work, also extended to incorporate explicitly property prices.” (p. 29)

Consequences." BIS Working Paper No. 284 (June).

"We review the available [financial instability] measurement methodologies and point out several weaknesses. In particular, we caution against heavy reliance on the current generation of macro stress tests, arguing that they can lull policymakers into a false sense of security. Nonetheless, we argue that the 'fuzziness' in measurement does not prevent further progress towards an operational framework, as long as it is appropriately accounted for." (p. iii)

Brownlees, Christian T., and Robert F. Engle. 2011. "Volatility, Correlation and Tails for Systemic Risk Measurement.” Working paper, New York University (June).

"We propose an empirical methodology to measure systemic risk. Building upon Acharya et al. (2010), we think of the systemic risk of a financial institution as its contribution to the total capital shortfall of the financial system that can be expected in a future crisis. We propose a systemic risk measure (SRISK) that captures the expected capital shortage of a firm given its degree of leverage and Marginal Expected Shortfall (MES). MES is the expected loss an equity investor in a financial firm would experience if the overall market declined substantially. To estimate MES, we introduce a dynamic model for the market and firm returns. The specification is characterized by time varying volatility and correlation, which are modelled with the familiar TARCH and DCC. .. One year and a half before the Lehman bankruptcy, eight companies out of the SRISK top ten turned out to be troubled institutions." (p. 1)

Brunnermeier, Markus K., and Martin Oehmke. Forthcoming. "The Maturity Rat Race." Journal of Finance.

"We develop a model of endogenous maturity structure for financial institutions that borrow from multiple creditors. We show that a maturity rat race can occur: an individual creditor can have an incentive to shorten the maturity of his own loan to the institution, allowing him to adjust his financing terms or pull out before other creditors can. This, in turn, causes all other lenders to shorten their maturity as well, leading to excessively short-term financing. . . . Overall, firms are exposed to unnecessary rollover risk."

Brunnermeier, Markus K., and Lasse Heje Pedersen. 2009. “Market Liquidity and Funding Liquidity.” Review of Financial Studies, vol. 22, no. 6 (June):2201-2238.

"We provide a model that links an asset's market liquidity (i.e., the ease with which it is traded) and traders' funding liquidity (i.e., the ease with which they can obtain funding).... We show that, under certain conditions, margins are destabilizing and market liquidity and funding liquidity are mutually reinforcing, leading to liquidity spirals. The model explains the empirically documented features that market liquidity (i) can suddenly dry up, (ii) has commonality across securities, (iii) is related to volatility, (iv) is subject to 'flight to quality,' and (v) co-moves with the market." (p. 2201)

Brunnermeier, Markus K., and Yuliy Sannikov. 2012. "A Macroeconomic Model with a Financial Sector." Working paper, Princeton University (April): http://scholar.princeton.edu/markus/files/macro_finance.pdf.

"This paper studies the full equilibrium dynamics of an economy with financial frictions. Due to highly non-linear amplification effects, the economy is prone to instability and occasionally enters volatile episodes. Risk is endogenous and asset price correlations are high in down turns. In an environment of low exogenous risk experts assume higher leverage making the system more prone to systemic volatility spikes - a volatility paradox. Securitization and derivatives contracts lead to better sharing of exogenous risk but to higher endogenous systemic risk. Financial experts may impose a negative externality on each other by not maintaining adequate capital cushion.” 
Brunnermeier, Markus K., Thomas M. Eisenbach, and Yuliy Sannikov. 2011. "Macroeconomics with Financial Frictions: A Survey." Working paper, Princeton University (July): http://scholar.princeton.edu/markus/files/ survey_macroeconomics_frictions_0.pdf.

"This article surveys the macroeconomic implications of financial frictions. Financial frictions lead to persistence and when combined with illiquidity to nonlinear amplification effects. Risk is endogenous and liquidity spirals cause financial instability.” (p. 1)

Brunnermeier, Markus K., Gary Gorton, and Arvind Krishnamurthy. 2011. "Risk Topography.” Working paper, Princeton University (March): http://scholar.princeton.edu/markus/files/risk_topography.pdf.

"The aim of this paper is to conceptualize and design a risk topography that outlines a data acquisition and dissemination process that informs policymakers, researchers and market participants about systemic risk. Our approach emphasizes that systemic risk (i) cannot be detected based on measuring cash instruments, e.g., balance sheet items and income statement items; (ii) typically builds up in the background before materializing in a crisis; and (iii), is determined by market participants' response to various shocks." (p. 1)

Brunnermeier, Markus, Andrew Crocket, Charles Goodhart, Avinash D. Persaud, and Hyun Shin. 2009. "The Fundamental Principles of Financial Regulation." Geneva Reports on the World Economy 11 (June).

This book-length report by financial economists and macroeconomists argues that for financial regulation to be effective, it must be both macro-prudential (systemwide) as well as micro-prudential (concerned with individual institutions). Furthermore, the report argues these are very different functions and should be overseen by separate regulatory institutions. The report focuses on "countercyclical capital charges" as a way to moderate financial cycles.

Chacko, George, Sanjiv Das, and Rong Fan. 2011. “An Index-Based Measure of Liquidity.” Working paper (August).

The authors construct a new measure of liquidity risk by comparing the liquidity of an ETF with its underlying components. They find that it performs better than the more common, traditional liquidity risk factors used in the liquidity risk literature.

Chen, Long, David A. Lesmond, and Jason Wei. 2007. “Corporate Yield Spreads and Bond Liquidity.” Journal of Finance, vol. 62, no. 1 (February):119-149.

"We find that liquidity is priced in corporate yield spreads. Using a battery of liquidity measures covering over 4,000 corporate bonds and spanning both investment grade and speculative categories, we find that more illiquid bonds earn higher yield spreads, and an improvement in liquidity causes a significant reduction in yield spreads. Our findings justify the concern in the default risk literature that neither the level nor the dynamic of yield spreads can be fully explained by default risk determinants." (p. 119)

Cherkes, Martin, Jacob Sagi, and Richard Stanton. 2009. “A Liquidity-Based Theory of Closed-End Funds.” Review of Financial Studies, vol. 22, no. 1 (January):257-297.

"This paper develops a rational, liquidity-based model of closed-end funds (CEFs) that provides an economic motivation for the existence of this organizational form: They offer a means for investors to buy illiquid securities, without facing the potential costs associated with direct trading and without the externalities imposed by an open-end fund structure. . . In particular, the model explains why IPOs occur in waves in certain sectors at a time, why funds are issued at a premium to net asset value (NAV), and why they later usually trade at a discount. The authors also conduct an empirical investigation, which, overall, provides more support for a liquidity-based model than for an alternative sentiment-based explanation." (p. 257) 
Chordia, Tarun, Richard Roll, and Avanidhar Subrahmanyam. 2000. "Commonality in Liquidity." Journal of Financial Economics, vol. 56, no. 1 (April):3-28.

Rather than focusing on the liquidity of a single asset, which was standard in the literature until this paper, the authors find a commonality across assets. Spreads and other liquidity characteristics comove with the wider market.

Cochrane, John. 2010. Speech given at the 70th Annual Meeting of the American Finance Association, Atlanta (January).

John Cochrane gave the introductory speech at the American Finance Association's 2010 annual meeting on the naming of Darrell Duffie as AFA president. The speech highlighted Duffie's career and personal accomplishments.

Comerton-Forde, Carole, Terrence Hendershott, Charles M. Jones, Pamela C. Moulton, and Mark S. Seasholes. 2010. “Time Variation in Liquidity: The Role of Market-Maker Inventories and Revenues." Journal of Finance, vol. 65, no. 1 (February):295-331.

"We show that market-maker balance sheet and income statement variables explain time variation in liquidity, suggesting liquidity-supplier financing constraints matter. Using 11 years of NYSE specialist inventory positions and trading revenues, we find that aggregate market-level and specialist firm-level spreads widen when specialists have large positions or lose money. The effects are nonlinear and most prominent when inventories are big or trading results have been particularly poor." (p. 295)

Cúrdia, Vasco, and Michael Woodford. 2009. "Credit Spreads and Monetary Policy." Working paper, Columbia University (January): http://www.columbia.edu/ mw2230/CreditSpreads_0110.pdf.

"We consider the desirability of modifying a standard Taylor rule for a central bank's interest-rate policy to incorporate either an adjustment for changes in interest-rate spreads (as proposed by Taylor, 2008, and by McCulley and Toloui, 2008) or a response to variations in the aggregate volume of credit (as proposed by Christiano et al., 2007). We consider the consequences of such adjustments for the way in which policy would respond to a variety of types of possible economic disturbances, including (but not limited to) disturbances originating in the financial sector that increase equilibrium spreads and contract the supply of credit. We conduct our analysis using the simple DSGE model with credit frictions developed in Cúrdia and Woodford (2009a), and compare the equilibrium responses to a variety of disturbances under the modified Taylor rules to those under a policy that would maximize average expected utility. According to our model, a spread adjustment can improve upon the standard Taylor rule, but the optimal size is unlikely to be as large as the one proposed, and the same type of adjustment is not desirable regardless of the source of the variation in credit spreads. A response to credit is less likely to be helpful, and the desirable size (and even sign) of response to credit is even less robust to alternative assumptions about the nature and persistence of the disturbances to the economy."

de Jong, Frank, and Joost Driessen. 2006. "Liquidity Risk Premia in Corporate Bond Markets." Working paper (September): http://ssrn.com/abstract=686681.

"This paper explores the role of liquidity risk in the pricing of corporate bonds. We show that corporate bond returns have significant exposures to fluctuations in Treasury bond liquidity and equity market liquidity. Further, this liquidity risk is a priced factor for the expected returns on corporate bonds, and the associated liquidity risk premia help to explain the credit spread puzzle." (p. 1) 
Diamond, Douglas W., and Philip H. Dybvig. 1983. "Bank Runs, Deposit Insurance, and Liquidity.” Journal of Political Economy, vol. 91, no. 3 (June):401-419.

This is a classic paper on bank runs. It proceeds from the basic insight that because banks lend longin terms of maturity-but borrow short, they are vulnerable to runs. There are many potential equilibriums in terms of deposit banking, with a run being just one of them; under certain circumstances, government-insured deposit contracts can lead to improved equilibriums and a reduction in runs.

Diamond, Douglas W., and Raghuram G. Rajan. 2005. "Liquidity Shortages and Banking Crises." Journal of Finance, vol. 60, no. 2 (April):615-647.

"We show in this article that bank failures can be contagious. Unlike earlier work where contagion stems from depositor panics or contractual links between banks, we argue that bank failures can shrink the common pool of liquidity, creating, or exacerbating aggregate liquidity shortages. This could lead to a contagion of failures and a total meltdown of the system. Given the costs of a meltdown, there is a possible role for government intervention. Unfortunately, liquidity and solvency problems interact and can cause each other, making it hard to determine the cause of a crisis. We propose a robust sequence of intervention."

Duffie, Darrell. 1992. Dynamic Asset Pricing Theory. Princeton, NJ: Princeton University Press.

This textbook focuses on "the theory of asset pricing and portfolio selection in multiperiod settings under uncertainty. The asset pricing results are based on the three increasingly restrictive assumptions: absence of arbitrage, single-agent optimality, and equilibrium. These results are unified with two key concepts, state prices and martingales." (Preface)

- 2011a. How Big Banks Fail and What to Do About It. Princeton, NJ: Princeton University Press. This book explains the mechanics of failure by large broker/dealer banks as well as the rippling effects on the rest of the financial system. It also discusses the need for an improved regulatory and institutional framework to reduce the risk of failures and ways of reducing externalities caused by a failure.

—. 2011b. "Systemic Risk Exposures: A 10-by-10-by-10 Approach.” NBER Working Paper No. 17281 (July).

"Here, I present and discuss a '10-by-10-by-10' network-based approach to monitoring systemic financial risk. Under this approach, a regulator would analyze the exposures of a core group of systemically important financial firms to a list of stressful scenarios, say 10 in number. For each scenario, about 10 such designated firms would report their gains or losses. Each reporting firm would also provide the identities of the 10, say, counterparties with whom the gain or loss for that scenario is the greatest in magnitude relative to all counterparties. The gains or losses with each of those 10 counterparties would also be reported, scenario by scenario." (p. 1)

Gârleanu, Nicolae, and Lasse Heje Pedersen. 2011. "Margin-Based Asset Pricing and Deviations from the Law of One Price." Review of Financial Studies, vol. 24, no. 6 (June):1980-2022.

"In a model with heterogeneous-risk-aversion agents facing margin constraints, we show how securities' required returns increase in both their betas and their margin requirements. Negative shocks to fundamentals make margin constraints bind, lowering risk-free rates and raising Sharpe ratios of risky securities, especially for high-margin securities. Such a funding-liquidity crisis gives rise to 'bases,' that is, price gaps between securities with identical cash-flows but different margins." (p. 1980) 
Geanakoplos, J. 1997. "Promises Promises." In The Economy as an Evolving Complex System II. Edited by W. Brian Arthur, Steven N. Durlauf, and David Lane. Reading, MA: Addison-Wesley.

"In this paper I introduce the age-old problem of broken promises into the general equilibrium model, and I find that a new market dynamic emerges. Given the legal system and institutions, market forces of supply and demand will establish the collateral levels which are required to secure promises. . . . Many kinds of promises will not be traded, because that also economizes on collateral. Scarce collateral thus creates a mechanism for determining endogenously which assets will be traded, thereby helping to resolve a long standing puzzle in general equilibrium theory." (p. 1)

Gertler, Mark, and Peter Karadi. 2011. “A Model of Unconventional Monetary Policy.” Journal of Monetary Economics, vol. 58, no. 1 (January):17-34.

"We develop a quantitative monetary DSGE model with financial intermediaries that face endogenously determined balance sheet constraints. We then use the model to evaluate the effects of the central bank using unconventional monetary policy to combat a simulated financial crisis.... Within our framework the central bank is less efficient than private intermediaries at making loans but it has the advantage of being able to elastically obtain funds by issuing riskless government debt.... These benefits may be substantial." (p. 17)

Gertler, Mark, and Nobuhiro Kiyotaki. 2010. "Financial Intermediation and Credit Policy in Business Cycle Analysis." In Handbook of Monetary Economics, vol. 3. Edited by Benjamin M. Friedman and Michael Woodford. San Diego: Elsevier.

"We develop a canonical framework to think about credit market frictions and aggregate economic activity in the context of the current crisis. We use the framework to address two issues in particular: first, how disruptions in financial intermediation can induce a crisis that affects real activity; and second, how various credit market interventions by the central bank and the Treasury of the type we have seen recently, might work to mitigate the crisis. We make use of earlier literature to develop our framework and characterize how very recent literature is incorporating insights from the crisis." (p. 547)

Getmansky, Mila, Andrew W. Lo, and Igor Makarov. 2004. "An Econometric Model of Serial Correlation and Illiquidity in Hedge Fund Returns.” Journal of Financial Economics, vol. 74, no. 3 (December):529-609.

"The returns to hedge funds and other alternative investments are often highly serially correlated. In this paper, we explore several sources of such serial correlation and show that the most likely explanation is illiquidity exposure and smoothed returns. We propose an econometric model of return smoothing and develop estimators for the smoothing profile. ... We show that our estimated smoothing coefficients vary considerably across hedge-fund style categories and may be a useful proxy for quantifying illiquidity exposure." (p. 529)

Gorton, Gary B. 2010. Slapped by the Invisible Hand: The Panic of 2007. New York: Oxford University Press.

This book-length analysis argues that the 2007 crisis was a run in the shadow banking system, with the run on the repo market playing a central role. The book is adapted from three earlier papers by Gorton, two of which were presented at the Fed's Jackson Hole conferences in 2008 and 2009.

Gorton, Gary, and Andrew Metrick. 2011. "Securitized Banking and the Run on Repo.” Journal of Financial Economics (published electronically on $25 \mathrm{March}$ ).

"The panic of 2007-2008 was a run on the sale and repurchase market (the repo market), which is a very large, short-term market that provides financing for a wide range of securitization activities and financial institutions. Repo transactions are collateralized, frequently with securitized bonds. We refer to the combination of securitization plus repo finance as 'securitized banking' and argue that these 
activities were at the nexus of the crisis. We use a novel data set that includes credit spreads for hundreds of securitized bonds to trace the path of the crisis from subprime-housing related assets into markets that had no connection to housing. We find that changes in the LIB-OIS spread, a proxy for counterparty risk, were strongly correlated with changes in credit spreads and repo rates for securitized bonds. These changes implied higher uncertainty about bank solvency and lower values for repo collateral. Concerns about the liquidity of markets for the bonds used as collateral led to increases in repo haircuts, that is the amount of collateral required for any given transaction. With declining asset values and increasing haircuts, the US banking system was effectively insolvent for the first time since the Great Depression.”

Goyenko, Ruslan Y., Craig W. Holden, and Charles A. Trzcinka. 2009. "Do Liquidity Measures Measure Liquidity?” Journal of Financial Economics, vol. 92, no. 2 (May):153-181.

"Given the key role of liquidity in finance research, identifying high quality proxies based on daily (as opposed to intraday) data would permit liquidity to be studied over relatively long timeframes and across many countries. Using new measures and widely employed measures in the literature, we run horseraces of annual and monthly estimates of each measure against liquidity benchmarks. Our benchmarks are effective spread, realized spread, and price impact based on both trade and quote (TAQ) and Rule 605 data. We find that the new effective/realized spread measures win the majority of horseraces, while the Amihud [2002 ... .] measure does well measuring price impact." (p. 153)

Gray, Dale, and Andreas A. Jobst. 2010. "New Directions in Financial Sector and Sovereign Risk Management." Journal of Investment Management, vol. 8, no. 1 (First Quarter):23-28.

"The global financial crisis that began in 2007 has forced a re-examination of macroeconomics, financial economics, regulation, and risk management. ... What has been missing is comprehensive analysis of systemic financial risk and its links to sovereign risk. This essay illustrates how risk management tools and contingent claims analysis (CCA) can be applied in new ways to the financial system, to economic sectors and the national economy. . . . In this regard, a new framework called 'Systemic CCA' is described and an illustration of its application is given. This paper concludes with proposals on several new directions in managing financial sector and sovereign risk.” (p. 23)

Gray, Dale F., Robert C. Merton, and Zvi Bodie. 2008. "New Framework for Measuring and Managing Macrofinancial Risk and Financial Stability." Harvard Business School Working Paper No. 09-015 (August).

"This paper proposes a new approach to improve the way central banks can analyze and manage the financial risks of a national economy. It is based on the modern theory and practice of contingent claims analysis (CCA). . . The CCA approach is well-suited to capturing 'non-linearities' and to quantifying the effects of asset-liability mismatches within and across institutions. Risk-adjusted CCA balance sheets facilitate simulations and stress testing to evaluate the potential impact of policies to manage systemic risk.” (p. 3)

Gromb, Denis, and Dimitri Vayanos. 2002. "Equilibrium and Welfare in Markets with Constrained Arbitrageurs." Journal of Financial Economics, vol. 66, no. 2-3 (November-December):361-407.

"We propose a multiperiod model in which competitive arbitrageurs exploit discrepancies between the prices of two identical risky assets traded in segmented markets. Arbitrageurs need to collateralize separately their positions in each asset, and this implies a financial constraint limiting positions as a function of wealth. In our model, arbitrage activity benefits all investors because arbitrageurs supply liquidity to the market. However, arbitrageurs might fail to take a socially optimal level of risk, in the sense that a change in their positions can make all investors better off. We characterize conditions under which arbitrageurs take too much or too little risk." (p. 361) 
Grossman, Sanford J., and Merton H. Miller. 1988. "Liquidity and Market Structure." Journal of Finance, vol. 43, no. 3 (July):617-637.

"Market liquidity is modeled as being determined by the demand and supply of immediacy. Exogenous liquidity events coupled with the risk of delayed trade create a demand for immediacy. Market makers supply immediacy by their continuous presence and willingness to bear risk during the time period between the arrival of final buyers and sellers. In the long run the number of market makers adjusts to equate the supply and demand for immediacy. This determines the equilibrium level of liquidity in the market. The lower is the autocorrelation in rates of return, the higher is the equilibrium level of liquidity." (p. 12)

Harris, Larry. 2003. Trading and Exchanges: Market Microstructure for Practitioners. New York: Oxford University Press.

This book is a comprehensive overview of market microstructure with an emphasis on practical applications of interest to practitioners.

Hasbrouck, Joel. 2006. "Trading Costs and Returns for U.S. Equities: Evidence from Daily Data.” Working paper, New York University (August): http://pages.stern.nyu.edu/ jhasbrou/Research/GibbsEstimates2006/ ctc10.pdf.

"The effective cost of trading is usually estimated from transaction-level trade and quote data. This study proposes a Gibbs estimate that is based on daily closing prices. . . The results offer only weak support for the view that effective cost (as a characteristic) affects expected stock returns." (p. 1)

2007. Empirical Market Microstructure: The Institutions, Economics, and Econometrics of Securities Trading. New York: Oxford University Press.

This book is an overview of market microstructure, including its "institutions, economics, and econometrics," by Hasbrouck, who is one of the leading academic researchers in the field.

He, Zhigou, and Arvind Krishnamurthy. 2010. "Intermediary Asset Pricing.” Working paper.

"We present a model to study the dynamics of risk premia during crises in asset markets where the marginal investor is a financial intermediary. Intermediaries face a constraint on raising equity capital. When the constraint binds, so that intermediaries' equity capital is scarce, risk premia rise to reflect the capital scarcity. . . Infusing equity capital into intermediaries is particularly effective because it attacks the equity capital constraint that is at the root of the crisis in our model." (p. 1)

Holden, Craig W. 2009. "New Low-Frequency Spread Measures.” Journal of Financial Markets, vol. 12, no. 4 (November):778-813.

"I develop new spread proxies that pick up on three attributes of the low-frequency (daily) data: (1) price clustering, (2) serial price covariance accounting for midpoint prices on no-trade days, and (3) the quoted spread that is available on no-trade days." (p. 778)

Holmström, Bengt, and Jean Tirole. 2011. Inside and Outside Liquidity. Cambridge, MA: MIT Press.

"The purpose of this monograph is to offer an explanation of the demand for and the supply of liquid assets using insights from modern corporate finance and to study how such a theory can explain the pricing of assets, the role of liquidity management, real investments and also how this theory relates to some classic themes in macroeconomics and in international finance." (p. 2)

Houweling, Patrick, Albert Mentink, and Ton Vorst. 2005. "Comparing Possible Proxies of Corporate Bond Liquidity.” Journal of Banking E' Finance, vol. 29, no. 6 (June):1331-1358.

"We consider eight different proxies (issued amount, coupon, listed, age, missing prices, yield volatility, number of contributors and yield dispersion) to measure corporate bond liquidity and use 
a five-variable model to control for interest rate risk, credit risk, maturity, rating and currency differences between bonds. The null hypothesis that liquidity risk is not priced in our data set of euro corporate bonds is rejected for seven out of eight liquidity proxies. We find significant liquidity premia, ranging from 9 to 24 basis points. A comparison test between liquidity proxies shows limited differences between the proxies." (p. 1331)

Hu, Xing, Jun Pan, and Jiang Wang. 2010. "Noise as Information for Illiquidity.” NBER Working Paper No. 16468 (October).

"We propose a broad measure of liquidity for the overall financial market by exploiting its connection with the amount of arbitrage capital in the market and the potential impact on price deviations in US Treasuries. When arbitrage capital is abundant, we expect the arbitrage forces to smooth out the Treasury yield curve and keep the dispersion low. During market crises, the shortage of arbitrage capital leaves the yields to move more freely relative to the curve, resulting in more 'noise.' ... We find that our 'noise' measure captures episodes of liquidity crises of different origins and magnitudes and is also related to other known liquidity proxies." (p. 1)

Huberman, G., and D. Halka. 2001. "Systematic Liquidity." Journal of Financial Research, vol. 24, no. 2 (Summer):161-178.

This market microstructure paper looks at system-wide liquidity rather than just the liquidity of individual securities. Although it finds evidence of systemic liquidity, it does not find an explanation for what is driving it.

Ibbotson, Roger G., Jeffrey J. Diermeier, and Laurence B. Siegel. 1984. “The Demand for Capital Market Returns: A New Equilibrium Theory." Financial Analysts Journal, vol. 40, no. 1 (January/February):22-33.

This paper proceeds from the insight that "for many assets, these non-risk characteristics affect price, or expected return, even more than the risk characteristics." These non-risk characteristics include "taxation, marketability, and information costs." Noting that the CAPM and APT describe only the risk characteristics, the authors set forth the New Equilibrium Theory (NET) framework that "applies to all assets—including stocks and bonds, real estate, venture capital, durables and intangibles such as human capital—and incorporates all asset characteristics." (p. 22)

IMF, BIS, and FSB. 2009. "Guidance to Assess the Systemic Importance of Financial Institutions, Markets and Instruments: Initial Considerations.” Report to the G-20 Finance Ministers and Central Bank Governors. International Monetary Fund, Bank for International Settlements, and Financial Stability Board (October).

This report, developed for G-20 leaders, discusses different conceptual and analytical approaches to the assessment of systemically important financial institutions. It suggests potential guidelines in the form of "high level principles." The three policy issues discussed are (1) moral hazard by systemically important institutions, (2) information gaps in assessment, and (3) potential macro consequences and sources of financial risk.

Khandani, Amir E., and Andrew W. Lo. 2011. "Illiquidity Premia in Asset Returns: An Empirical Analysis of Hedge Funds, Mutual Funds, and U.S. Equity Portfolios." Quarterly Journal of Finance, vol. 1, no. 2 (June):205264.

"We establish a link between illiquidity and positive autocorrelation in asset returns among a sample of hedge funds, mutual funds, and various equity portfolios. For hedge funds, this link can be confirmed by comparing the return autocorrelations of funds with shorter vs. longer redemptionnotice periods." (p. 205) 
Kiyotaki, Nobuhiro, and John Moore. 1997. "Credit Cycles." Journal of Political Economy, vol. 105, no. 2 (April):211-248.

"This paper is a theoretical study into how credit constraints interact with aggregate economic activity over the business cycle. In particular, for an economy where credit limits are endogenously determined, we investigate how relatively small, temporary shocks to technology or income distribution might generate large, persistent fluctuations in output and asset prices.” (pp. 211-212)

Korinek, Anton. 2011. "Systemic Risk-Taking: Amplification Effects, Externalities, and Regulatory Responses." ECB Working Paper No. 1345 (May).

"This paper analyzes the efficiency of risk-taking decisions in an economy that is prone to systemic risk, captured by financial amplification effects that occur in response to strong adverse shocks. It shows that decentralized agents who have unconstrained access to a complete set of Arrow securities choose to expose themselves to such risk to a socially inefficient extent because of pecuniary externalities that are triggered during financial amplification. The paper develops an externality pricing kernel that quantifies the state-contingent magnitude of such externalities and provides welfaretheoretic foundations for macro-prudential policy measures to correct the distortion.” (p. 1)

Kyle, Albert S. 1985. “Continuous Auctions and Insider Trading.” Econometrica, vol. 53, no. 6 (November):13151335 .

"A dynamic model of insider trading with sequential auctions, structured to resemble a sequential equilibrium, is used to examine the informational content of prices, the liquidity characteristics of a speculative market, and the value of private information to an insider.” (p. 1315)

Lee, Kuan-Hui. 2005. “The World Price of Liquidity Risk.” Dissertation, Fisher College of Business, The Ohio State University (November): http://finance.eller.arizona.edu/documents/seminars/2005-6/ KHLee.PriceLiqdtyRisk01-06.pdf.

"This paper specifies and tests an equilibrium asset pricing model with liquidity risk at the global level. The analysis encompasses 25,000 individual stocks from 48 developed and emerging countries around the world from 1988 to 2004. Though we cannot find evidence that the liquidity-adjusted capital asset pricing model of Acharya and Pedersen (2005) holds in international financial markets, crosssectional as well as time-series tests show that liquidity risks arising from the covariances of individual stocks' return and liquidity with local and global market factors are priced. Furthermore, we show that the US market is an important driving force of world-market liquidity risk. We interpret our evidence as consistent with an intertemporal capital asset pricing model (Merton (1973)) in which stochastic shocks to global liquidity serve as a priced state variable."

Lerner, Josh, Antoinette Schoar, and Wan Wongsunwai. 2007. "Smart Institutions, Foolish Choices: The Limited Partner Performance Puzzle.” Journal of Finance, vol. 62, no. 2 (April):731-764.

"The returns that institutional investors realize from private equity differ dramatically across institutions. Using detailed, hitherto unexplored records, we document large heterogeneity in the performance of investor classes: endowments' annual returns are nearly $21 \%$ greater than average. Analysis of reinvestment decisions suggests that endowments (and to a lesser extent, public pensions) are better than other investors at predicting whether follow-on funds will have high returns." (p. 731)

Lesmond, D.A., J.P. Ogden, and C.A. Trzcinka. 1999. "A New Estimate of Transaction Costs." Review of Financial Studies, vol. 12, no. 5 (October):1113-1141.

The authors create a new measure of liquidity in terms of transaction costs based on incidence of zero return days, reducing the data needs used in other transaction cost estimates. 
Lewellen, Jonathan, Stefan Nagel, and Jay Shanken. 2010. "A Skeptical Appraisal of Asset Pricing Tests." Journal of Financial Economics, vol. 96, no. 2 (May):175-194.

"In this paper, we review and critique the empirical methods used in the (asset pricing) literature. We argue that asset-pricing tests are often highly misleading, in the sense that apparently strong explanatory power (high cross-sectional $R^{2} \mathrm{~s}$ and small pricing errors) in fact provides quite weak support for a model. We offer a number of suggestions for improving empirical tests and evidence that several proposed models don't work as well as originally advertised.” (p. 174)

Longstaff, Francis A., Sanjay Mithal, and Eric Neis. 2005. "Corporate Yield Spreads: Default Risk or Liquidity? New Evidence from the Credit Default Swap Market." Journal of Finance, vol. 60, no. 5 (October):2213-2253.

"We use the information in credit default swaps to obtain direct measures of the size of the default and nondefault components in corporate spreads. We find that the majority of the corporate spread is due to default risk. This result holds for all rating categories and is robust to the definition of the riskless curve. We also find that the nondefault component is time varying and strongly related to measures of bond-specific illiquidity as well as to macroeconomic measures of bond market liquidity." (p. 2213)

Lou, Xiaoxia, and Ronnie Sadka. 2011. "Liquidity Level or Liquidity Risk? Evidence from the Financial Crisis." Financial Analysts Journal, vol. 67, no. 3 (May/June):51-62.

"Although generally considered safe assets, liquid stocks underperformed illiquid stocks during the financial crisis of 2008-2009. The performance of stocks during the crisis can be better explained by their historical liquidity betas (risk) than by their historical liquidity levels. Stocks with different historical liquidity levels did not experience different returns after controlling for liquidity risk. The authors' findings highlight the importance of accounting for both liquidity level and liquidity risk in risk management applications." (p. 1)

Nagel, S. Forthcoming. "Evaporating Liquidity.” Review of Financial Studies.

"The returns of short-term reversal strategies in equity markets can be interpreted as a proxy for the returns from liquidity provision. Analysis of reversal strategies shows that the expected return from liquidity provision is strongly time-varying and highly predictable with the VIX index.... The results point to withdrawal of liquidity supply, and an associated increase in the expected returns from liquidity provision, as a main driver behind the evaporation of liquidity during times of financial market turmoil, consistent with theories of liquidity provision by financially constrained intermediaries."

O'Hara, Maureen. 1995. Market Microstructure Theory. Cambridge, MA: Blackwell Publishing.

This book is a canonical text in market microstructure. The organization consists of an examination of "the main theoretical models developed to address inventory-based issues. There is then an extensive examination and discussion of the information-based models, with particular attention paid to the linkage with rational expectations models and learning models. The concluding chapters are concerned with price dynamics and with applications of the various models to specific microstructure problems."

Pástor, Luboš, and Robert F. Stambaugh. 2003. “Liquidity Risk and Expected Stock Returns.” Journal of Political Economy, vol. 111, no. 3 (June):642-685.

"This study investigates whether market-wide liquidity is a state variable important for asset pricing. We find that expected stock returns are related cross-sectionally to the sensitivities of returns to fluctuations in aggregate liquidity. Our monthly liquidity measure, an average of individual-stock measures estimated with daily data, relies on the principle that order flow induces greater return reversals when liquidity is lower." (p. 642) 
Reinhart, Carmen, and Vincent R. Reinhart. 2010. "After the Fall." Paper presented at the Federal Reserve Bank of Kansas City's 2010 Economy Policy Symposium, Jackson Hole, Wyoming (August).

"This paper examines the behavior of real GDP (levels and growth rates), unemployment, inflation, bank credit, and real estate prices in a twenty-one-year window surrounding selected adverse global and country-specific shocks or events. ... We present evidence that the decade of relative prosperity prior to the fall was importantly fueled by an expansion in credit and rising leverage that spans about 10 years; it is followed by a lengthy period of retrenchment that most often only begins after the crisis and lasts almost as long as the credit surge."

Reinhart, Carmen M., and Kenneth S. Rogoff. 2009. This Time It's Different: Eight Centuries of Financial Folly. Princeton, NJ: Princeton University Press.

This book-length study by Reinhart and Rogoff looks at commonalities of financial crisis across countries and centuries, including the false belief before a crisis that somehow "this time is different."

Roll, Richard. 1984. "A Simple Implicit Measure of the Effective Bid-Ask Spread in an Efficient Market." Journal of Finance, vol. 39, no. 4 (September):1127-1139.

The author introduces a new measure of the bid-ask spread based on serial covariance of price changes. He finds this implicit measure is empirically related to firm size.

Sadka, R. Forthcoming. "Hedge-Fund Performance and Liquidity Risk." Journal of Investment Management.

"This paper demonstrates that liquidity risk as measured by the covariation of fund returns with unexpected changes in aggregate liquidity is an important predictor of hedge-fund performance. ... The returns are independent of share restriction, pointing to a possible imbalance between the liquidity a fund offers its investors and the liquidity of its underlying positions. Liquidity risk seems to account for a substantial part of hedge-fund performance.” (p. 1)

Sarkar, Asani, and Jeffrey Shrader. 2010. "Financial Amplification Mechanisms and the Federal Reserve's Supply of Liquidity during the Financial Crisis." Economic Policy Review, vol. 16, no. 1 (August):55-74.

"Our study focuses on two financial amplification mechanisms of relevance to the crisis: balance sheet amplifiers and adverse-selection amplifiers. We also interpret the actions of the Federal Reserve in the context of the literature on financial amplification mechanisms." (p. 55)

Shleifer, Andrei, and Robert W. Vishny. 1997. "The Limits of Arbitrage." Journal of Finance, vol. 52, no. 1 (March):35-55.

This influential paper proceeds from the insights that arbitrage is risky and also requires capital. The result is that arbitrage can become ineffective in extreme circumstances, with prices diverging far from fundamentals. These constraints can create pricing anomalies that cannot be arbitraged away, even in seemingly efficient markets.

Siegel, Laurence B. 2008. “Alternatives and Liquidity: Will Spending and Capital Calls Eat Your 'Modern' Portfolio?” Journal of Portfolio Management, vol. 35, no. 1 (Fall):103-114.

"High allocations to alternative investments by investors, such as foundations and endowments, raise infrequently discussed concerns about liquidity. As the percentage of assets under management invested in alternatives rises, the availability of liquid equities and bonds available to meet spending requirements, capital calls, and margin calls plummets. A series of simulations shows how severe this problem can become in bear markets. The remedy for this problem is to ladder gradually into illiquid assets, so that expected future cash flows from these assets partially or fully offset capital calls and other cash requirements. New and enthusiastic investors in illiquid alternative investments sometimes forget this principle. By adhering to it, an alternatives program can be successful, but not on an unlimited scale. It is also necessary to hold a considerable portion of a portfolio in liquid stocks and bonds.” 
Silber, William L. 1991. "Discounts on Restricted Stock: The Impact of Illiquidity on Stock Prices.” Financial Analysts Journal, vol. 47, no. 4 (July/August):60-64.

The author finds that creditworthy companies offer substantial discounts of $30 \%$ on restricted stock (stock that must be held for two years when the paper was written). This discount illustrates the impact of illiquidity on equity prices.

Sullivan, Rodney N., Steven P. Peterson, and David T. Waltenbaugh. 2010. "Measuring Global Systemic Risk: What Are Markets Saying about Risk?” Journal of Portfolio Management, vol. 37, no. 1 (Fall):67-77.

"The authors explore the features that characterize market environments through time. The authors first demonstrate how market distress impacts return distributions and then propose a global systemic risk indicator that jointly connects market conditions across asset classes using a multivariate failure model. . . . By combining high-frequency information that measures changes in key variables across time and across markets, the proposed risk hazard model yields valuable insight into the changing nature of market risks over time, both within and across markets."

Swensen, David. 2000. Pioneering Portfolio Management: An Unconventional Approach to Institutional Investment. New York: Free Press.

This book by the Yale Endowment's David Swensen describes Yale's portfolio management philosophy and Swensen's general principles for endowment management success, which include a heavy allocation to high-performing alternative asset managers.

Taylor, John B. 2009. “Defining Systemic Risk Operationally.” In Ending Government Bailouts as We Know Them. Edited by Kenneth E. Scott, George P. Shultz, and John B. Taylor. Stanford, CA: Hoover Press.

"The purpose of this chapter is to review recent writings and research on systemic risk and assess whether the term is operational enough to be used as a guideline or criterion to determine whether the failure of a particular firm would create significant economic damage or to classify firms into a systemically important group in advance. Despite the frequent discussions in policy circles, I find that the term remains ... vague and amorphous." (p. 35)

Teo, Melvyn. 2011. "The Liquidity Risk of Liquid Hedge Funds.” Journal of Financial Economics, vol. 100, no. 1 (April):24-44.

"This paper evaluates hedge funds that grant favorable redemption terms to investors. Within this group of purportedly liquid funds, high net inflow funds subsequently outperform low net inflow funds by $4.79 \%$ per year after adjusting for risk. The return impact of fund flows is stronger when funds embrace liquidity risk.... These results resonate with the theory of funding liquidity by Brunnermeier and Pedersen (2009).” (p. 24)

Tovar, Camilo. 2008. "DSGE Models and Central Banks." Bank for International Settlements Working Papers No. 258 (September).

The author discusses the progress as well as the drawbacks in DSGE modeling. It is written primarily from a central bank user's perspective. The author finds that although DSGE models offer a coherent framework for informing policy discussions, current models still have significant limitations.

Watanabe, Akiko, and Masahiro Watanabe. 2008. "Time-Varying Liquidity Risk and the Cross Section of Stock Returns.” Review of Financial Studies, vol. 21, no. 6 (November):2449-2486.

"This paper studies whether stock returns' sensitivities to aggregate liquidity fluctuations and the pricing of liquidity risk vary over time. We find that liquidity betas vary across two distinct states: one with high liquidity betas and the other with low betas. . . O Our results are consistent with a model of liquidity risk in which investors face uncertainty about their trading counterparties' preferences." (p. 3966) 